\title{
Początki i rozwój chrześcijaństwa w Czechach za pierwszych Przemyślidów (do końca X wieku) $)^{* *}$
}

Pomimo sąsiedztwa z południowo-wschodnimi terenami państwa frankijskiego (Bawaria, Turyngia), plemiona słowiańskie z Kotliny Czeskiej z chrześcijaństwem zetknęły się dopiero w IX wieku. Znaczący wpływ na stworzenie warunków dla szerzenia akcji misyjnej także wśród plemion słowiańskich osiadłych w strefie środkowego Dunaju i okolicznych ziem miał przebieg wojny frankijsko-awarskiej ${ }^{\mathrm{I}} \mathrm{w}$ latach 790-805. Sukces, jaki w początkowej fazie konfliktu osiągnęły wojska karolińskie, operujące na zachodnich i południowo-zachodnich terenach chaganatu awarskiego, wpłynął na decyzję o chrystianizacji nowo zdobytych ziem. W 796 roku w obozie dowodzącego kampanią awarską Pippina miał miejsce synod, któremu przewodniczył patriarcha akwilejski Paulinus II, a w którym uczestniczyli duchowni bawarscy oraz pochodzący z terenu północno-wschodniej Italii. Znaczenie synodu polegało na tym, że opracowano wówczas zasady dotyczące przeprowadzania akcji misyjnej na terenach

1 W. Pohl, Die Awaren. Ein Steppenvolk in Mitteleuropa 567-822 n. Chr., München 2002, s. 312-323.

*Dr hab. Krzysztof Polek - profesor UP, pracuje w Katedrze Historii Średniowiecza Instytutu Historii i Archiwistyki Uniwersytetu Pedagogicznego im. KEN w Krakowie. Zainteresowania badawcze: dzieje i kultura Europy w V-XI w., dzieje i kultura Słowiańszczyzny zachodniej we wczesnym średniowieczu, etnogeneza i kultura ludów i plemion w Europie wczesnośredniowiecznej, historia gospodarcza Europy wczesnego średniowiecza, historia środowiska (environmental history), historia historiografii.

**Tekst powstał w ramach realizacji projektu badawczego „Historia i kultura dawnych Słowian (do końca XVIII w.)” (grant przyznany przez Narodowy Program Rozwoju Humanistyki, nr projektu: II H I202I68I). 
zasiedlonych przez Słowian i ludność awarską, a pozostających do niedawna pod władzą chaganatu ${ }^{2}$. Podjęto także wówczas zasadnicze decyzje odnośnie podziału stref wpływów diecezji uczestniczących w planach misyjnych na omawianych terenach. Wprawdzie ustalenia te dotyczyły przede wszystkim ziem, jakie Frankowie zdobyli na Awarach w trakcie kampanii (na południe od Dunaju oraz w południowo-wschodniej części strefy alpejskiej), lecz w rzeczywistości nie pozostało to bez wpływu także na okoliczne tereny, sąsiadujące z chaganatem awarskim. Wraz z rozszerzeniem wpływów politycznych państwa karolińskiego w Europie środkowej zaistniały dogodne warunki dla prowadzenia systematycznej działalności chrystianizacyjnej.

\section{Początki chrześcijaństwa w Czechach}

Obszar Kotliny Czeskiej znalazł się w bezpośrednim sąsiedztwie państwa karolińskiego nie tylko od zachodu, lecz także od południa, co nie pozostało bez wpływu na wzajemne relacje i kontakty również w sferze religijnej. Z racji położenia geograficznego ziemie czeskie graniczyły z diecezjami ratyzbońską i passawską. Ostatnia z wymienionych była zaangażowana w chrystianizację Panonii, a także ziem położonych wzdłuż Dunaju, tj. w kierunku wschodnim i południowo-wschodnim. Zatem już na przełomie VIII i IX wieku w najbliższym sąsiedztwie ziem czeskich (Kotlina Czeska i Morawy) prowadzone były działania chrystianizacyjne wśród miejscowej ludności. Miało to znaczenie dla przebiegu tego procesu zarówno wśród okolicznych plemion słowiańskich, jak i tych osiadłych w dorzeczu Wełtawy i górnej Łaby.

Inną konsekwencją zmian politycznych, do jakich doszło w omawianym okresie, było bezpośrednie sąsiedztwo z monarchią karolińską i wejście w sferę jej wpływów. Podstawowe informacje źródłowe dotyczące wczesnych relacji frankijsko -czeskich z początku IX wieku zawierają roczniki z Metzu³, Chronicon Moissacense ${ }^{4}$, Annales regni francorum ${ }^{5}$, a także biografia Karola Wielkiego autorstwa Einharda ${ }^{6}$. Źródła frankijskie przekazały też informacje o dwóch wyprawach, jakie Karol Wielki podjął przeciwko plemionom czeskim tuż przed i po zakończeniu wojny awarskiej. Enigmatyczne relacje autorów frankijskich nie pozwalają jednak na poznanie szczegółów przebiegu, jak też efektów tych działań. To powoduje, że

2 Conventus episcoporum ad ripas Danubii a. 796, ed. A. Werminghoff, Monumenta Germaniae Historica (dalej MGH), Legum sectio III. Concilia aevi Karolini, II. I, ed. A. Werminghoff, Hannover, Leipzig 1906, nr 20, s. 172-176; R. Bratož, La cristianizzazione degli Slavi negli atti del Convegno "ad ripas Danubii" e del Concilio di Cividale, in XII Centenario del concilio di Cividale 796-1996. Convegno storico-teologico. Atti, cur. S. Piussi, Udine 1998, s. I45-190, zwł. s. I54-179; K. Polek, Chrystianizacja Moraw i Stowacji w okresie przedcyrylometodiańskim, [w:] Chrystianizacja „Mtodszej Europy", red. J. Dobosz, J. Strzelczyk, M. Matla, (UAM Seria Historia, nr 228), Poznań 2016, s. 55-84, zwł. s. 55-59.

3 Annales Mettenses priores, a.a. 805, ed. B. von Simson, MGH, Scriptores rerum Germainicarum in usum scholarum (dalej MGH SRG), vol. Io, Hannoverae-Lipsiae I905, s. 93-94.

4 a.a.805, ed. G.H. Pertz, MGH Scriptores 2, Hannoverae I829, s. 257-259.

5 ARF, a. a. 805, ed. G.H. Pertz, rec. F. Kurtze, MGH SRG, Hannoverae I895 (Neudruck 1950), s. I20.

6 Vita Karoli magni, ed. O. Holder-Egger, MGH SRG 25, Hannover I9II, c. I3, s. I6; c. I5, s. I8. 
historycy są zgodni w ocenie, iż efekty kampanii były nikłe7. Dotyczy to przede wszystkim ustalenia charakteru relacji frankijsko-czeskich w sferze politycznej i tego, czy plemiona z terenu Kotliny Czeskiej pozostawały w zależności trybutarnej od monarchii karolińskiej. W tekście Einharda znajduje się opis rozległości ziem państwa Karola Wielkiego, a wśród podbitych i zależnych od jego władzy ludów i plemion pojawiają się także Bohemani ${ }^{8}$. W opisie tym mamy do czynienia z odzwierciedleniem zarówno realnego zasięgu karolińskich wpływów politycznych, jak też występowaniem reminiscencji geografii antycznej, mających na celu podkreślenie roli i znaczenia Karola jako władcy, w zakresie zdobyczy

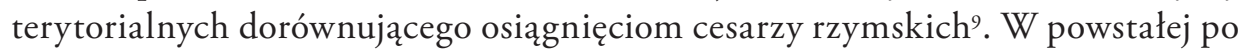
upadku chaganatu awarskiego sytuacji politycznej na terenie Europy Środkowej plemiona czeskie na pewno znalazły się w strefie wpływów państwa karolińskiego (wskazuje na to Ordinatio Imperii 8I7 czy udział ich wysłanników na zjeździe we Frankfurcie nad Menem w 822 roku), jednak nie znajdujemy dowodów wskazujących na prowadzenie wśród nich działalności misyjnej.

Czechy nie są bowiem typowym przykładem chrystianizacji, rozumianej najczęściej jako akcja misyjna prowadzona przez grupę duchownych wśród ludności pogańskiej, wraz z nauczaniem i przygotowaniem do przyjęcia chrztu. Pierwsza wzmianka źródłowa informująca o kontaktach z chrześcijaństwem pochodzi dopiero z 845 roku, kiedy - według relacji autora Annales Fuldenses, czternastu książąt czeskich dobrowolnie przyjęło chrzest w Ratyzbonie ${ }^{10}$. Wydarzenie to jest dość niezwykłe z tego względu, że nic nie wiadomo o jakiejkolwiek akcji misyjnej, która by poprzedzała tę ceremonię. Pozostawiając na uboczu prowadzoną w literaturze przedmiotu dyskusję o politycznych przyczynach i następstwach tego kroku oraz o tym, czy książęta, którzy przyjęli chrzest, byli reprezentantami wszystkich plemion, jakie zamieszkiwały obszar Kotliny Czeskiej, czy też wszyscy oni pochodzili z jednego plemienia ${ }^{\mathrm{II}}$, warto zaznaczyć,

7 H. Łowmiański, Początki Polski, t. 4, Warszawa 1970, s. 399-400.

8 Einhard, Vita Karoli Magni, c. I3, s. I6.

9 Wskazują na to reminiscencje geografii antycznej wykorzystane przez kronikarza we fragmencie opisu wschodniej granicy państwa Karola Wielkiego (Einhard, Vita Karoli Magni, c. 15, s. 17-18), opierającej się o Wisłę, co w warunkach historycznych IX wieku było rażącym anachronizmem. Zob. H. Remitz, Grenzen und Grenzüberschreitung in karolingischen Mitteleuropa, [w:] Grenze und Differentz in frühen Mittelalter, Hrgs. von W. Pohl, H. Remitz (Forschungen zur Geschichte des Mittelalters, Bd I), Denkschriften Österreichischen Akademiae der Vissenschaften, Bd 287, Wien 2000, s. 145-I66; N. Lozovsky, Roman geography and ethnography in the Carolingian Empire, "Speculum” 2006:81, s. 325-364; idem, Carolingian geographical tradition: was is geography?, „Early Medieval Europe” 1996:5(I), s. 25-43.

10 Annales Fuldenses, a. 845, [w:] Quellen zur karolingischen Reichsgeschichte 3, Hrsg. R. Rau, (Ausgewählte Quellen zur deutsche Geschichte des Mittelalters, Bd 7), Darmstadt 1975, s. 35 (dalej cyt. Ann. Fuld.).

11 Kwestią, która nasuwa się w odniesieniu do relacji roczników fuldajskich dotyczącej chrztu I4 duces w 845 roku, jest ustalenie, czy reprezentowali oni wszystkie, czy tylko niektóre z plemion osiadłych na terenie Kotliny Czeskiej. Liczba podana przez autora roczników jest mniejsza od tej występującej w karolińskiej zapisce zwanej Geografem Bawarskim, gdzie podano, że Boheimare mają 
że mamy do czynienia ze spotykanym w ówczesnych realiach przejawem indywidualnej konwersji. Badacze przypuszczali, że był to rezultat działalności misyjnej biskupstwa ratyzbońskiego, choć brak ewidentnych śladów (wzmianki w źródłach pisanych czy znaleziska archeologiczne), mogących potwierdzić jej występowanie. Niewątpliwie natomiast wydarzenie z 845 roku wskazuje na występowanie wcześniejszych kontaktów czesko-bawarskich (z duchowieństwem ratyzbońskim), niekoniecznie o charakterze kościelnym.

Czy dla książąt czeskich wzorem do naśladowania był książę morawski Mojmir I, który przyjął chrzest wraz z ludem z rąk biskupa passawskiego Reginharda w 83I roku, czy może był to przejaw zabezpieczenia się przed imperialną polityką sąsiedniego państwa? Nie wiadomo. Brak też wyraźnych podstaw do łączenia decyzji książąt czeskich o przyjęciu chrztu z dążeniem do przebudowy ustrojowej i utworzenia organizacji państwowej. Tendencja taka wystąpiła znacznie później i to dopiero przy silnym wsparciu ze strony władcy Moraw, Świętopełka I. Fakt, że pomimo braku poświadczenia wcześniejszej działalności misyjnej poprzedzającej konwersję, chrzest przyjęli wszyscy książęta wskazuje, że mamy do czynienia z decyzją o wyraźnie politycznym charakterze.

Chrzest z 845 roku nie pozostawił żadnych trwałych śladów ${ }^{12}$, nieznane są także następstwa, jakie mógł przynieść plemionom osiadłym w Kotlinie Czeskiej, zarówno w ich kulturze duchowej, jak też materialnej (budownictwo sakralne, artefakty symbolizujące nową religię). Dlatego też częściej można spotkać się z opinią, że decyzja książąt czeskich miała charakter bardziej polityczny aniżeli kościelny ${ }^{13}$. Wskazują na to wydarzenia, do jakich doszło niebawem, a wynikające z polityki Ludwika Niemca wobec wschodnich sąsiadów. Wkrótce po zawarciu rozejmu i zakończeniu wojny domowej (843) władca ten przystąpił do odbudowy i umocnienia strefy wpływów, jaką za rządów Karola Wielkiego i Ludwika Pobożnego państwo

Is civitates (B. Horák, D. Trávníček, Descriptio civitatum ad septentrionalem plagam Danubii (tzv. Bavarský geograf), Rozpravy ČSAV, Řada Společenských věd, 1956, 66(2), s. 2 in quia sunt civitetes XV). Dawniejsza historiografia łączyła wymienionych książąt z plemionami osiadłymi głównie w północnozachodniej części Kotliny Czeskiej, zob. V. Novotny, České dějiny. D. I, 1: Od nejstarš dob do smrti knieje Oldřicha, Praha 1912, s. 284; R. Nový, Die Anfänge des böhmischen Staates, Bd I: Mitteleuropa im 9. Jahrhundert, Praha 1968, s. 195-199. Toteż przyjmuje się, że obecni w Ratyzbonie książęta byli reprezentantami wszystkich plemion osiadłych w Kotlinie Czeskiej, a określenie Boheimare, wymienione w Geografie Bawarskim odnosi się do wszystkich plemion osiadłych na tym obszarze. Zatem I4 książąt wspomnianych w rocznikach z Fuldy było reprezentantami ogółu plemion czeskich. Por. B. Horák, D. Trávníček, Descriptio civitatum, op. cit., s. I8-19; D. Třeštík, Počatký Přemyslovců. Vstup Čechů do dějin (530-935), Praha 1997, s. 84.

12 O wydarzeniu tym brak jakiejkolwiek informacji w kronice Kosmasa.

13 H. Łowmiański (Początki Polski, t. 4, s. 4OI) łączył wydarzenie z 845 roku z procesem budowy państwowości wśród plemion czeskich, choć świadomy był różnic, jakie w tym zakresie występowały pomiędzy Morawami a terenem Kotliny Czeskiej. W rezultacie książęta zdecydowali się na przyjęcie chrztu poza własnym terenem, co wymieniony badacz uważał za krok w kierunku przebudowy ustroju wewnętrznego. Zob. D. Třeštík, Počatký Přemyslovců, dz. cyt., s. 86, 94. 
karolińskie posiadało na wschód od ujścia Łaby aż do środkowego Dunaju ${ }^{14}$. Dobrze ilustrują to działania podjęte przez niego w stosunku do plemion północno-zachodnio-połabskich, a także przeciwko plemionom osiadłym w Kotlinie Czeskiej ${ }^{15}$.

Interesującym znaleziskiem związanym z wydarzeniami z 845 roku jest kielich z Kolína, stanowiący część inwentarza okazałego pochówku (zachowały się fragmenty drewnianej obudowy), zawierającego szkielety mężczyzny oraz kobiety. Wewnątrz komory grobowej archeolodzy natrafili na bogate wyposażenie (miecz, ostrogi, naszyjnik z amuletem oraz paciorkami ze szkła, szklane wazy, guzy, ozdoby, okucia, kaptorga), a przede wszystkim na ozdobny, częściowo pozłacany kielich wykonany ze srebra, będący najprawdopodobniej wyrobem jednej z nadreńskich pracowni rzemiosła artystycznego doby karolińskiej ${ }^{16}$. Jest to kielich wotywny, a fakt, że znalazł się w składzie inwentarza grobowego, wskazuje na wysoką pozycję społeczną zmarłego. Znalezisko z Kolína nastręcza problemy nie tylko natury chronologicznej ${ }^{17}$, lecz przede wszystkim interpretacyjnej. Charakter kielicha jako przedmiotu liturgicznego jest bardzo wyraźny, jednak w omawianym przez nasz przypadku nietypowe jest miejsce jego znalezienia, tj. grób świecki. Może to sugerować, że kielich z Kolína utracił swoją liturgiczną funkcję, stając się artefaktem świeckim. Odnośnie okoliczności ${ }^{18}$, w jakich przedmiot ten dotarł na teren Kotliny Czeskiej, najczęściej wskazuje się na pobyt czternastu książąt czeskich w Ratyzbonie $^{19}$, gdzie zostali ochrzczeni w 845 roku. Wątpliwości nasuwa jednak fakt, że kielich znaleziony został w grobie świeckim, a takie przedmioty z reguły nie występowały u osób, które przyjęły chrzest. Najczęściej były to okolicznościowe plakietki

14 Ordinatio Imperii (8I7) oraz geneza wspomnianej zapiski zwanej Geografem Bawarskim, która obrazuje potencjał demograficzny i militarny plemion słowiańskich za wschodnią granicą najpierw imperium karolińskiego, a następnie jego państwa sukcesyjnego, jakim była monarchia wschodniofrankijska.

15 Ann. Fuld., a. 847-849, s. 37-39; a. 855-857, s. 45-47.

16 Analogie karolińskie widoczne są w odniesieniu do naczyń wykonanych ze szkła oraz miecza pochodzącego najprawdopodobniej z którejś pracowni w Nadrenii. Natomiast ozdoby i biżuteria kobieca posiadają analogie z wyrobami pochodzącymi z terenu sąsiednich Moraw. R. Turek, Velkomoravský horizont v českých mohyláh ( $k$ otázce moravsko-českých vztahì), „Památky Archeologické” (dalej Pam. Arch.), I963:54(I), s. 223-233; M. Šolle, Stara Kourim a projevy velkomoravské hmotné kultury v Čechach, Praha I966, s. 84-86; J. Werner, Zum Cundpold-Kelch von Petöhäza, „Jahrbuch des Römisch-Germanisches Zentralmuseum in Mainz” I966:13, s. 265-278, zwł. s. 265, tab. 30 i 266, ryc. I; I. Boná, Cundpold fecit, „Acta Archaeologica Academiae Scientiarum Hungaricae” I966:I8, s. 279-325. Natomiast N. Profantová, Archeology and written sources on eight-to tenth-century Bohemia, „Early Medieval Europe” 2009:I7(3), s. 286-3IO, zwł. s. 29I sugeruje, że przedmioty znajdujące się w grobie męskim, ze względu na jego okazały charakter, mogły być symbolami władzy.

17 M. Lutovský, Kolinský knižecí hrob: ad fontes, „Sborník Národního Muzea v Praze. Rada A-Historie” I994:48(3-4), s. 6I-63 kielich datuje na pierwszą połowę IX wieku natomiast biżuterię i ozdoby na drugą połowę tego stulecia (styl wielkomorawski).

18 Czy jest możliwe aby był to dar, jaki otrzymali przyjmujący chrzest książęta? Zazwyczaj nowo ochrzczeni otrzymywali podarki takie jak plakietki chrzestne, dewocjonalia, czy zapinki z wizerunkiem świętego/świętej.

19 Z. Měžínský, České zeme od prichodu Slavanů po Velkou Moravu. II, Praha 2006, s. 663. Podobne stanowisko reprezentuje M. Lutovský, Kolinský knižecí hrob, s. 65-66. 
chrzcielne, dewocjonalia a nawet cenne przedmioty świeckiego przeznaczenia, gdy przyjmującym chrzest była osoba z kręgu władzy bądź elity społecznej. Ponadto kwestią otwartą pozostaje datowanie grobu ${ }^{20}$, albowiem jego inwentarz, zawierający przedmioty reprezentujące wysoką wartość artystyczną, mieści się ramowo w IX wieku. Ostatnio jednak przeważa pogląd, że kielich pochodzi z pierwszej połowy omawianego stulecia ${ }^{21}$, co stanowi ważny argument dla datowania pochówku mężczyzny. Bez względu na kwestie związane z pochodzeniem grobu z Kolína, to, biorąc pod uwagę miejsce znalezienia kielicha, nie może być on postrzegany jako bezpośredni efekt chrystianizacji. Mógł dotrzeć na teren Kotliny Czeskiej poprzez kontakty handlowe, bądź jako łup wojenny, jednak na obecnym etapie badań nie sposób jednoznacznie rozstrzygnąć tej kwestii.

Grób z Kolína nie stanowi wyjątku. Z terenu północno-zachodniej części Kotliny Czeskiej pochodzi równie okazały grób z miejscowości Želénkýn ${ }^{22}$, datowany na interesujący nas okres. Zawartość jego inwentarza wskazuje, że zmarła wywodziła się z wyższej grupy społecznej, co potwierdzają ozdoby i biżuteria pochodzenia morawskiego (kolczyki, typowe dla znalezisk na stanowiskach morawskich guzy - gombiki, zawieszki oraz ozdoby stroju). Uwagę zwraca nietypowy sposób pochówku, tj. umieszczony pod kurhanem, co dodatkowo stanowiło formę wyróżnienia pozycji, jaką zmarła zajmowała w społeczeństwie. Natomiast interesującym znaleziskiem są złote krzyżyki, mogące stanowić wskazówkę dotyczącą preferencji wyznaniowej zmarłej²

Jednym z głównych przejawów chrystianizacji była zmiana obrządku pogrzebowego, tj. przejście od kremacji do inhumacji. W odniesieniu do Kotliny Czeskiej nowy zwyczaj praktyk funeralnych pojawił się już na przełomie VIII i IX wieku. Jednak, w przeciwieństwie do sąsiednich Moraw, na interesującym nas obszarze (przede wszystkim na terenie północno-zachodniej części Kotliny Czeskiej) archeolodzy natrafiają najczęściej na małe skupiska grobów szkieletowych usytuowanych w pobliżu osad, brak natomiast dużych nekropolii. Inhumacja rozpowszechniała się stosunkowo wolno. W trakcie badań archeologicznych stwierdzono częste występowanie pochówku szkieletowego w grobie kurhanowym, do rozpowszechnionego zwyczaju należało też wyposażanie zmarłych w przedmioty, jakich używali za życia (broń, narzędzia, biżuteria i ozdoby stroju ${ }^{24}$.

20 Z. Měžínský, České země, s. 224-225.

21 Tamże, s. 226. Natomiast drobne przedmioty, jak biżuteria, ozdoby i okucia, dekorowane typowymi motywami występującymi w znaleziskach z doby wielkomorawskiej, umieszcza się w tamtejszym horyzoncie czasowym.

22 N. Profantová, J. Militký, Das Fürstengrab von Želénký, [w:] Europa Mitte von 1ooo. Beiträge zur Geschichte, Kunst und Archäologie, Bd 3, Hrsg. von A. Wieczorek, H-M. Hinz, Stuttgart 200o, s. I88-191. Odkrycia dokonano w połowie XIX wieku, zob. K. Sklenáŕ, Pưvodni zpráva o výzkumu slovenské knižeci mohyly u Želének v r. I850, „Časopis národního muzea. Řada historická” 1985: 154, s. 6I-8I.

23 N. Profantová, Archeology and written sources, s. 292, ryc. 2(I-6).

24 Z. Krumphanzlová, Počátký křestanstvi v Čechách ve svétle archeolohických pramenü, Pam. Arch., 1971:62(2), s. 406-455, zwł. s. 417-418) zwraca uwagę na uchwytne w materiale archeologicznym wpływy pochodzące z sąsiednich Moraw, występujące aż do połowy lat dziewięćdziesiątych IX wieku. 


\section{Chrzest Borzywoja}

Kolejna, tym razem znajdująca potwierdzenie źródłowe, faza rozwoju chrześcijaństwa w Czechach przypadała na okres rządów Borzywoja, pierwszego historycznego księcia czeskiego z dynastii Przemyślidów. Związana była z oddziaływaniem państwa (wielko-)morawskiego na plemiona osiadłe w Kotlinie Czeskiej. Jakkolwiek kontakty władców morawskich z plemionami czeskimi były znane od dawna ${ }^{25}$, to dopiero Borzywoj I był pierwszym, który - w oparciu o pomoc Świętopełka I, przystąpił do umacniania swojej władzy. Drogą do tego była chrystianizacja. O chrzcie Borzywoja I nadmienił Kosmas w dziesiątym rozdziale pierwszej księgi Kroniki, informując także o udziale w ceremonii arcybiskupa Metodego ${ }^{26}$. Kronikarz ponownie powrócił do tej kwestii w czternastym rozdziale pierwszej księgi, wzmiankując, że chrzest Borzywoja I odbył się w obrządku katolickim ${ }^{27}$. Druga z podanych przez kronikarza informacji nie odpowiada innym, bardziej wiarygodnym świadectwom, nie mówiąc już o zapisanej w kronice dacie samego wydarzenia. $\mathrm{Na}$ tej podstawie historycy datują chrzest wymienionego księcia czeskiego na czas po powrocie Metodego z internowania w Bawarii i po zawarciu pokoju w Forhcheim (874). Tym samym Kosmas potwierdził zależność księcia Borzywoja od Świętopełka I, władcy państwa morawskiego, co - zdaniem większości badaczy, należy datować na lata 882-88428. Od tego też czasu, aż do swej śmierci (około 890) Borzywoj był księciem sprawującym władzę w imieniu Świętopełka I na terenie Kotliny Czeskiej.

Więcej szczegółów dotyczących okoliczności i przebiegu chrztu Borzywoja I poznajemy dzięki tzw. Legendzie Krystiana, przedstawiającej żywot św. Wacława, w której autor ukazał obszernie genealogię Przemyślidów. Zarówno czas powstania, jak też autorstwo tekstu wzbudzają liczne kontrowersje. Główną osią sporu jest odpowiedź na pytanie, czy tekst powstał w końcu X wieku, czy znacznie później? Ma ona zasadnicze znaczenie i wykracza daleko poza sferę zwykłej dyskusji naukowej. Obecnie źródło to uważane jest za wiarygodne, a związki Krystiana z rodem Przemyślidów (był synem Bolesława I) podnosi wagę informacji zawartych w tekście ${ }^{29}$. Dotyczy to przede wszystkim wzmianki o okolicznościach chrztu Borzywoja I, dlatego też często Krystiana nazywa się pierwszym czeskim historykiem. Autor przy

25 Dokonywano także koordynacji działań militarnych przeciwko monarchii wschodniofrankijskiej, zob. relacje Ann. Fuld., a. 846, 848, 849, s. 36-39; Annales Bertiniani, a. 847, [w:] Quellen zur karolingischen Reichsgeschichte 3, Hrsg. R. Rau (Ausgewählte Quellen zur deutsche Geschichte des Mittelalters, Bd 6), Darmstadt, I96I, s. 72.

26 Cosmae Pragensis Chronica Boemorum, ed. B. Bretcholz, MGH SRG, nova series 2 Berolini 1923, lib. I, c. IO, s. 22 (dalej cyt. Kosmas, Chronica).

27 Tamże, I, c. I4, s. 32. Kronikarz wiadomość tę zapisał pod datą 894 rok.

28 W literaturze przedmiotu chrzest Borzywoja umieszczany był w szerokim kontekście chronologicznym, od 873 aż po 890 rok. zob. Z. Měžínský, Českézeme, s. 85I (zestawienie dotychczasowych poglądów w tej kwestii) oraz s. 840, 863; H. Łowmiański, Początki Polski, t. 4, s. 415; D. Třeštík, Borivoj und Svatopluk. Die Enstehung des böhmischen Staates und Großmähren, [w:] Großmähren und die Anfänge der tschechoslowakischen Staatlichkeit, Hrsg. J. Poulík, B. Chropovský und kollektiv, Praha 1986, s. 311-344, zwł. s. 317-319; tenże, Počatký Přemyslovcú, s. 312-347, zwł. s. 338. 
pisaniu pierwszej starosłowiańskiej legendy o św. Wacławie wykorzystał informacje źródłowe dotyczące życia i śmierci świętych Ludmiły i Wacława, a także wykazał się znajomością tekstów staro-cerkiewno-słowiańskich (wątek dotyczący Metodego). Uzupełnienia i dodatki Krystiana jako autora były niewielkie, co znacząco podnosi wiarygodność tekstu, który powstał w latach 992-994 i zawiera cenne i nieznane innym przekazom informacje ${ }^{30}$ dotyczące udziału Wielkich Moraw w szerzeniu chrześcijaństwa wśród plemion Czechów oraz okoliczności chrztu Borzywoja. Miało to miejsce na dworze Świętopełka I, który zaprosił księcia na ucztę. Posadzono go nie przy stole wraz z chrześcijanami, tylko poza nim, wraz z innymi poganami. Rozmowa z Metodym ukazała Borzywojowi korzyści (roztoczył przed księciem perspektywę przejęcia władzy od swoich zwierzchników), jakie może odnieść, jeżeli zdecyduje się na przyjęcie chrztu ${ }^{31}$. Chrzest księcia, jego najbliższej rodziny i towarzyszących osób miał miejsce na trzeci dzień po wspomnianej uczcie. Następnie Borzywoj I, hojnie obdarowany przez Świętopełka I, powrócił w rodzinne strony a w drodze powrotnej towarzyszył mu duchowny imieniem Kaich (Caych), który w grodzie Levý Hradec wzniósł kościół pw. św. Klemensa ${ }^{32}$.

Nie wiadomo, czy przebieg interesującego nas spotkania wyglądał tak, jak przekazał to Krystian, czy raczej wykorzystał on jeden z popularnych sposobów, jakimi starano się nakłonić pogańskich książąt do konwersji. Zdarzenie to, analogicznie jak w przypadku czternastu książąt z 845 roku, nosiło znamiona konwersji indywidualnej. Wspomniany wyżej Kaich, który wraz z otoczeniem Borzywoja przybył do Czech, miał za zadanie przede wszystkim sprawowanie służby bożej dla tej niewielkiej grupy nowych chrześcijan. Nie prowadził on akcji o charakterze misyjnym, za czym przemawia brak informacji o innych kapłanach i diakonach działających w jego najbliższym otoczeniu.

Po powrocie do Czech Borzywoj I nie zyskał jednak wewnątrz plemienia akceptacji dla dokonanego wyboru. Przeciwnie - spotkał się z opozycją, na czele której stanął Strojmir, pochodzący z wysokiego rodu, a przebywającemu dotychczas na

29 Do rehabilitacji tzw. legendy Krystiana przyczyniły się studia J. Pekařa, Die Wenzels- und Ludmila - legenden und die Echtheit Christians, Praha 1906; R. Jakobson, Minor natove sources for the early history of the Slavic Church, „Harvard Slavic Studies” 1954, 2, s. 39-73; J. Ludvíkovský, The GreatMoravan tradition In the Io century Bohemia and Christian's legend, [w:] Magna Moravia. Sborník k IIoo. Výroči príchodu byzatské mise na Moravu, ed. J. Macủrek (Spisy Unversity J.E. Purkyně v Brně. Filosofická fakulta, I02), Praha 1965, s. 525-566; Z. Fiala, Hlavni pramen legendy Kristiánovy, [Rozpravy ČSAV, Ǩada společenských věd, 84(I)] Praha 1974, s. 8-28; aktualny stan badań nad tekstem legendy Krystiana przedstawia D. Kalhous, Legenda Christiani and modern historiography (East and Central Eastern Europe in the middle ages, 450-1450, vol. 34), Leiden-Boston 2015, poz. 7.

30 D. Třeštík, Počatký Přemyslovcü, Praha 198I, s. 45-66, gdzie autor omówił pochodzenie relacji źródłowych i powiązania pomiędzy tekstem Krystiana a innymi przekazami dotyczącymi św. Wacława i św. Ludmiły.

31 Christianus monachus, c. 2, Magne Moraviae Fones Historici 2: Textus biographici, hagiographici, liturgici, ed. D. Bartoňková, L. Havlík, J. Ludvíkovský, Z. Masařík, R. Večerka (Spisy University J.E. Purkyně v Brně. Filosofická fakulta, II8), Brno 1967, s. 193-194. 
wygnaniu w Bawarii. W rezultacie wybuchu buntu książę zmuszony był udać się na dwór Świętopełka I, który udzielił mu pomocy. Przydzielił oddział wojowników przy pomocy których Borzywoj zdołał pokonać rebeliantów i odzyskać rządy wśród Czechów. Relacjonując te zdarzenia, Krystian ujął je w typowy dla historiografii chrześcijańskiej schemat, co jednak nie musi oznaczać, że jego relacja nie posiada znamion wiarygodności ${ }^{33}$. Przy tej okazji autor żywota potwierdził zależność polityczną księcia czeskiego od Świętopełka morawskiego.

Borzywoj I po powrocie i objęciu władzy nad plemieniem w charakterze votum ufundował kościół pw. NMP, co nastąpiło najprawdopodobniej pomiędzy 885 a 889/890 rokiem. Został on wzniesiony na terenie grodu praskiego, w miejscu, gdzie odbywały się uroczystości związane z intronizacją księcia ${ }^{34}$. Stanowiło to symbol o czytelnej wymowie - tak politycznej jak też religijnej.

Po podporządkowaniu plemion czeskich, Świętopełk ${ }^{35}$ powierzył Borzywojowi zwierzchnictwo nad nimi, a dzięki wsparciu militarnemu ze strony władcy morawskiego książę mógł wzmocnić swoją pozycję kosztem plemiennych rywali. Jego dodatkowym atutem było posiadanie Pragi i kontrola miejsca, gdzie dokonywano wyboru księcia oraz gdzie znajdował się kamienny tron. Poprzez wybudowanie świątyni chrześcijańskiej doszło do sakralizacji tego miejsca.

33 Motyw księcia Ingo i jego chrzest w analogicznych okolicznościach jak Borzywoja I. Według D. Třeštíka, Počatký Premyslovci̊, s. 334 w relacji tej mamy do czynienia z dwoma tradycjami rodową (a także pochodzącą spoza niej, związaną ze Strojmirem) oraz wywodzącą się ze środowiska kleru praskiego.

34 W trakcie prac wykopaliskowych przeprowadzonych na terenie grodu praskiego archeolodzy odkryli cmentarzysko zawierające groby wojowników, których broń, oporządzenie jeździeckie i ozdoby wskazywały na powiązania z terenem wielkomorawskim. To wymownie wskazuje na charakter pomocy, jaką uzyskał Borzywoj i kontrolę miejsca, gdzie dokonywano intronizacji księcia. Zob. przez I. Borkovský, Kostel Panny Marie na Pražskem hradě, Pam. Arch., I953:44(I) s. I29-200; tenże, Kotazce nejsteršich kostelú na Pražskem hradě, Pam. Arch., I960:5I(2), s. 332-387; A. Merhautová, Raně středověka architektura v Čechách, s. 216-218; eadem, Nejsterši dosud znmý kostel na Pražskšm hradě, „Folia Historica Bohemia” 1983:5, s. 8I-93. Czas budowy określono w oparciu o inwentarz grobów znajdujących się wewnątrz, jak i na zewnątrz kościoła. Dominującym elementem była ceramika, która pod względem wykonania i ornamentyki nawiązywała do wyrobów z terenu sąsiednich Moraw. Aktualny stan badań archeologiczno-architektonicznych przedstawia J. Frolík, Z. Smetánka, K archeologickému studiu Pražského hradě, Archeologické Rozhlady, 1998: 50(3), s. 293-307; J. Frolík, Nejstarši cirkevni architektura na Pražském hradě-současný stav poznani, [w:] Velká Morava mezi Východem a Západem, ed. L. Galuška, P. Kouřil, Z. Měřínský, (Spisy Archeologického Ústavu AV ČR 17), Brno 200I, s. IO7-II3, zwł. s. IO7-IO8. Kościólek p.w. NPMarii datowany jest na około $883 / 884$ r. a jego wnętrzu odkryto groby księcia Spitygniewa I i jego żony, zob. Z. Smetánká, E. Vlček, J. Eisler, Hrobki knižete Spytygnýva I, „Folia Bohemica historica” 1998: 6, s. 6I-80.

35 Zdaniem większości historyków najbardziej odpowiednim momentem podporządkowania plemion w Kotlinie Czeskiej władzy Świętopełka I były lata pomiędzy 882 a 885 , tj. po zakończeniu walk morawsko-bawarskich na terenie Panonii, a przed śmiercią arcybiskupa Metodego, zob. H. Łowmiański, Początki Polski, s. 4I5; D. Třeštík, Počatký Přemyslovců, s. 338 przyjmował, że krótka kampania militarna przebiegła wiosną 883 roku. 
Następny etap związany z przekształceniem tej części grodu praskiego przypadał na okres rządów Spitygniewa I, kiedy wzniesiony został gród, przez co książę uzyskał kontrolę nad miejscem na którym dokonywano ceremonii wyboru i intronizacji władcy (Žíží). Przynależność Czech do morawskiego systemu politycznego (884-895) przyczyniła się do utrwalenia modelu zwierzchniej władzy księcia oraz przyspieszyła proces budowy organizacji państwowej. Jej wyznacznikiem stały się grody zlokalizowane na obszarze centralnej części Kotliny Czeskiej. Atutem Borzywoja I i jego następców była dogodne położenie domeny Przemyślidów w centralnej części Kotliny Czeskiej, gdzie zbiegały się ważne szlaki komunikacyjne (dorzecze środkowej Wełtawy). Miejsce to zapewniało także dostęp do zasobów surowcowych (rudy metali, drewno, kamień, glina). Kosmas bardzo ogólnikowo wspomniał o zasługach pierwszego historycznego księcia czeskiego dla rozwoju chrześcijaństwa, odsyłając czytelnika swojej kroniki, między innymi do dokumentu fundacyjnego biskupstwa praskiego i kościoła morawskiego oraz do żywota św. Wacława ${ }^{36}$.

Konsekwencją przyjęcia chrztu przez Borzywoja I i epizodu (wielko-)morawskiego w dziejach plemion Kotliny Czeskiej był - poza sferą polityczną, także rozwój budownictwa sakralnego. Przybyłemu wraz z księciem Kaichowi przypisuje się budowę pierwszego kościoła w Czechach pw. św. Klemensa w grodzie Levý Hradec. Badania archeologiczne, jakie przeprowadził I.Borkovský w latach I939-I94I wykazały, że świątynia została wzniesiona na rzucie centralnym (rotunda jednoabsydowa) pod poziomem posadzki obecnego kościoła ${ }^{37}$. W pobliżu świątyni archeolodzy natrafili na cmentarz, co ułatwiło ustalenie chronologii budowli. Jak wykazały nowsze badania archeologiczno-architektoniczne ${ }^{38}$, rotunda nie była przebudowywana w późniejszym czasie, dzięki czemu zachowała pierwotny kształt. Czas budowy ustalono na IX wiek.

\section{Następcy Borzywoja}

Innym, ważnym ośrodkiem grodowym państwa Przemyślidów był w omawianym okresie Budeč (okr. Kladno), gdzie z fundacji księcia Spitygniewa I na terenie grodu wzniesiono świątynię ${ }^{39}$ pw. św. Piotra (kolejnego patrona, św. Pawła, dodano w okresie

36 Kosmas, Chronica, I, c. Io s. 22 oraz c. 15, s. 35.

37 I. Borkovský, Levý Hradec. Nejsterši sidlo Přemyslovců, Praha 1965.

38 A. Merhautová, Raně středověka architektura v Čechách, Praha, I97I, s. I54 -I55; A. Merhautová, D. Třeštík, Románské uměni v Čechách a na Moravè, Praha I983, s. 35; J. Sláma, Středni Čechy $v$ raném strédověku. III. Archeologie o počatkách prèmyslovského státu (Acta Instituci Praehistorici Universitatis Carolinae Pragensis, Praehistorica, I4), Praha I988, s. 33-34.

39 Crescente fide, ed. J. Emler, Fontes rerum Bohemicarum I, Prague I873, s. I83. M. Šolle, Rotunda sv. Petra a Pavla na Budči, PA I990:8I(I), s. I40-207. Badania archeologiczne reliktów rotundy wykazały jej powstanie w okresie późnowielkomorawskim. Położona była w pobliżu rezydencji książęcej, a całość tego obszaru została odgrodzona od pozostałego terenu grodziska palisadą. W ten sposób podkreślono znaczenie tego miejsca będącego centrum władzy książęcej i mającego charakter rezydencjonalny. W pobliżu gródka zlokalizowano cmentarz zawierający groby osób reprezentujących wysoki status społeczny, o czym świadczą przedmioty znalezione przy zmarłych (biżuteria i ozdoby, zawieszki). Wśród znalezisk uwagę zwraca krzyżyk (niekompletnie zachowany), 
późniejszym). Chronologię budowli określono w oparciu o zachowane fragmenty jej fundamentów ${ }^{40}$ (sposób układania kamieni, skład chemiczny zaprawy), a także zawartości inwentarza grobu znajdującego się w pobliżu kościoła. Ustalono je na przełom IX/X wieku. Kolejny kościół na terenie grodziska Budeč wzniesiono w X stuleciu. Usytuowany był nieopodal rotundy. Nowa świątynia była budowlą jednonawową i nosiła wezwanie Najświętszej Panny Marii. Oba kościoły stały na terenie tzw. Akropolu, czyli tam, gdzie znajdowała się siedziba książęca. Budeč, podobnie jak Levý Hradec, Libušin, Tetin czy Stara Boleslav, należał do czołowych grodów domeny Przemyślidów, rozciągającej się w środkowej części Kotliny Czeskiej.

Po śmierci Świętopełka I Czesi wyłamali się spod dotychczasowej zależności, przyjmując - w nieznanych bliżej okolicznościach, zwierzchność monarchii wschodniofran-

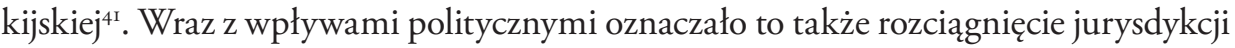
biskupstwa ratyzbońskiego na obszar Kotliny Czeskiej. Z nominacji biskupa działał na tym terenie archiprezbiter Paweł ${ }^{42}$, kierujący pracą podległych mu duchownych, a jego siedziba znajdowała się najprawdopodobniej w Pradze, przy kościele św. Jerzego. Przypuszcza się, że był on mnichem pochodzącym z klasztoru pw. św. Emmerama, w którym edukację duchową przechodził biskup Regensburga, Tuto. Według relacji Crescente fide, za rządów księcia Wacława I do Czech przybywali duchowni nie tylko z sąsiedniej Bawarii, lecz także ze Szwabii oraz z innych stron, przywożąc ze sobą relikwie i święte księgi, co wskazuje na starania władcy o wyposażenie powstających kościołów ${ }^{43}$. Jeżeli mówimy o zasięgu chrześcijaństwa wśród plemion osiadłych w Kotlinie Czeskiej w IX-X wieku, to nie wykraczało ono poza domenę Przemyślidów. Dobrym tego przykładem jest relacja Krystiana o walce Wacława I z księciem rezydującym w grodzie Kouřim (Stara Kouřim), który wszczął rebelię przeciwko Przemyślidzie ${ }^{44}$. Niewykluczone, że był to przejaw rywalizacji pomiędzy obu władcami o rozszerzenie swego panowania wśród okolicznych plemion. Gród kurzymski został zniszczony

wykonany z pozłacanego brązu, wykazujący analogie do znalezisk z Mikulczyc, zob. M. Šolle, Objev mikulčicko-blatnického křižku na Budeči i jeho význam, AR 1980:32(3), s. 265-273. Nekropolię datuje się na schyłek IX wieku.

40 J. Sláma, Středni Čechy v raném středověku, III, s. I4, ryc. 3. A. Merhautová, Raně středověka architektura v Čechách, s. 98-Ioo; A. Bartošková, I. Štefan, Raně středověka Budeč-pramená Kladna a bilance poznatkì. (K problematyce funkci centrálni lokality), AR 2006: 58(4), s. 724-757, zwł. s. 735-739 budownictwo sakralne.

41 Ann. Fuld., a. 895 , s. 126.

42 Crescende fide, s. 185.

43 Legenda Christiani, Vita et pasio Santi Wenceslai et Sance Ludmile ave eius, ed. J. Ludvíkovský, Praha 1978, c. 6, s. 60 (dalej cyt. Legenda Christiani). Jak podkreśla A. Kuźmiuk-Ciekanowska, Święty i historia. Dynastia Przemyślidów i jej bohaterowie w dziele mnicha Krystiana, Kraków 2007, s. 178, Wacław ukazany został przez Krystiana jako władca prowadzącym działalność duszpasterską.

44 R. Nový, Slavníkovici v raně stréedověkých Čechach, [w:] Slavnikovici ve středověkém písemnictví, red. R. Nový, J. Sláma, J. Zachová, Praha 1978, s. 36; D. Třeštíka, Počatký Přemyslovců, 389-418, gdzie autor przedstawił relacje polityczne czesko-niemieckie za rządów króla Henryka I na tle sytuacji politycznej w Europie Środkowej - rywalizacja sasko-bawarska, najazdy Madziarów, ekspansja saska w kierunku wschodnim. 
w pierwszej tercji X wieku. Badania archeologiczne przeprowadzone na jego terenie ujawniły zachowanie drewnianych reliktów świątyni znajdującej się na terenie cmentarzyska, a pozostałości kultury materialnej wskazują na powiązania z terenem sąsiednich Moraw ${ }^{45}$. R. Nový epizod ten łączył z działaniami o charakterze antysaskim, do których doszło Połabiu w latach 928-929. Władcy chorwaccy w Czechach mieli nawiązać kontakty z Ludolfingami, co nie pozostało bez wpływu na dotychczasowe stosunki pomiędzy Przemyślidami a Sławnikowiczami. Ich skutkiem była walka księcia Wacława I z władcą kurzimskim ${ }^{46}$.

Na przełomie IX i pierwszej ćwierci X wieku obserwujemy postępujący - a oparty o sieć grodów ${ }^{47}$, powstałą na terenie środkowej części Kotliny Czeskiej, proces konsolidacji władzy Przemyślidów. W pierwszej tercji X wieku Przemyślidzi podejmowali działania dla rozszerzenia wpływów poza tzw. domeną. Celem stali się lokalni książęta, naczelnicy plemienni, czego przykładem była walka księcia Wacława I z władcą rezydującym w Kouřimí. W ośrodkach władzy Przemyślidów wznoszono obiekty sakralne, a ich liczba od czasu chrztu Borzywoja I uległa zwiększeniu. Korelacja informacji pochodzących ze źródeł pisanych (głównie są to starosłowiańskie legendy związane ze św. Wacławem) oraz wyników badań archeologicznych pozwala stwierdzić istnienie wówczas - poza kościołami, które powstały w okresie przynależności Czech do państwa wielkomorawskiego, następujących świątyń: w Budeczu ${ }^{48}$ - fundatorem był Spitygniew I, w grodzie Tetin ${ }^{49}$, w Starej Boleslavi ${ }^{\circ \circ}$ (pw. św. Kosmy i Damiana), w Pradze ${ }^{51}$, a także bazyliki św. Jerzego wzniesionej z inicjatywy Wratysława oraz rotundy św. Wita ${ }^{52}$, powstałej za czasów Wacława I (na terenie grodu praskiego).

Wzrost aktywności na polu budownictwa sakralnego obserwujemy za następców Borzywoja I. W kronice Kosmas scharakteryzował bardzo zdawkowo powyższe dokonania, nadmieniając tylko o zasługach następców pierwszego chrześcijańskiego księcia z dynastii Przemyślidów ${ }^{53}$. Według przekazu Legendy Krystiana Spitygniew miał - podobnie jak jego ojciec - budować kościoły i dbać o duchownych, gromadzić wokół siebie kapłanów i kleryków ${ }^{54}$. Na tle pozostałych grodów wyróżniała się Praga ${ }^{55}$,

45 M. Šolle, Kouřrim v mladši a pozdni době hradištní, PA 1969: 60(I), s. I-I24; idem, Stará Kourim a projevy velkomorawské hmotné kultury v Čechách, Praha 1966.

46 Legenda Christiani, c. Io, s. Ioo.

47 J. Sláma, Středni Čechy III, s. 7I-84.

48 A. Bartošková, I. Štefan, Raně středověká Budeč, s. 735-739; J. Sláma, Středni Čechy III, s. I5-16.

49 J. Sláma, Středni Čechy III, s. 6I-62.

50 Tamże, s. 53-54.

51 J. Frolík, Nejstarši cirkevni architektura na Pražském hradě, s. I07-II3.

52 A. Merhautová, Raně středověka architektura v Čechách, s. 216-218; J. Frolík, Nejstarší církevní architektura na Pražském hradě, s. I09-IIO.

53 Kosmas, Chronica, I, c. I5, s. 35.

54 Legenda Christiani, c. 3, s. 26: fundator extitut ecclesiarem Dei, congregator sacerdotum clericorumque.

55 Jej rozwój przypadał na drugą połowę X wieku, o czym świadczy fakt, że przed tym okresem nie była zbyt często wzmiankowana w źródłach. Przed relacją Ibrahima ibn Jakuba o Pradze nadmienił Widukind, Rerum gestarum Saxonicarum libri tres, ed. G. Waitz, K.A. Kehr, recognovit P. Hirsch, MGH SRG, 30, 
w której - poza kościołem Najświętszej Marii Panny fundacji Borzywoja, za Bratysława I wzniesiono kościół pw. św. Jerzego. W oparciu o charakterystyczny typ (rotundy) powstałych wówczas budowli D. Třeštík ${ }^{56}$ łączył je z wpływami wielkomorawskimi. Odnosiło się to także do ekipy realizującej te przedsięwzięcia od strony technicznej. Obecnie w badaniach nad rozprzestrzenianiem się rotund na omawianych terenach (strefa środkowego Dunaju) należy zwrócić uwagę nie tylko na wschodni kierunek, lecz przede wszystkim na tereny południowo-zachodnie (Bawaria, Niemcy środkowe, oddziaływania za pośrednictwem strefy alpejskiej) oraz Saksonię. Szczególnie odnosi się to do pierwszego i ostatniego z wymienionych krajów, z którymi państwo Przemyślidów utrzymywało w omawianym okresie intensywne kontakty.

Kolejny etap rozwoju chrystianizacji nastąpił po rozszerzeniu władzy Przemyślidów na pozostałe plemiona osiadłe w Kotlinie Czeskiej, dotychczas będące w luźnej od nich zależności. Twórcą silnego i rozległego państwa czeskiego był Bolesław I (935-976), którego dojście do władzy odbyło się w dramatycznych okolicznościach - po zamordowaniu Wacława I (935) w Starej Boleslawi ${ }^{57}$. Symbolem zmian stał się upadek grodów będących siedzibami książąt plemiennych, a w nowo powstałych ośrodkach władzy Bolesław I osadził drużyny, będące gwarantem respektowania władzy zwierzchniej Przemyślidów. Wykorzystując dogodny moment, jakim było zaangażowanie Węgrów w akcje militarne w krajach zachodniej Europy, książę zajął północno-zachodnią część Moraw a także Poważe (zachodnia część Słowacji) ${ }^{58}$. Defensywna postawa Madziarów po klęsce w bitwie pod Augsburgiem (955) stworzyła dogodną okoliczność dla podjęcia przez Bolesława I ekspansji w kierunku północno-wschodnim ${ }^{59}$. Nie wdając się w szczegóły dotyczące gospodarczych korzyści, które znalazły się u podstaw tej

do rozwoju terenów podgrodzia (ob. Stare Miasto). W rejonie obecnego mostu Karola natrafiono na pozostałości umocnień drewniano-ziemnych wałów oraz fosy, a także fragment wyłożonej drewnem drogi, prowadzącej do przeprawy (most) przez rzekę, zob. N. Profantová, Archeology and written sources, s. 300, przyp. 21.

56 Počatký Přmyslovců, s. 406.

57 Kosmas, Chronica, I, c. I7, s. 35-36, gdzie kronikarz podał datę śmierci Wacława - 28 IX 929. W sprawie datowania tego zdarzenia, 929 bądź 935 rok, oraz okoliczności wewnętrznych, które miały wpływ na tę tragedię, zob. uwagi D. Třeštíka, Počatký Přemyslovců, s. 209-260 i M. Lutovský, Bratrovrah a tvirrce státu. Živet a doba knižete Boleslava I, Praha I998, s. 67-72.

58 J. Žemlička, Expanze, krize a obnova Čech v letech 935-1055, „Česky Časopis Historický” 1995:93(2), s. 205-221, zwł. s. 208; M. Matla-Kozłowska, Pierwsi Przemyślidzi i ich państwo (od X do potowy XI wieku). Ekspansja terytorialna i jej polityczne uwarunkowania, Poznań 2008, s. 234 wskazuje na przyłączenie Moraw przez Bolesława I w dwóch etapach: pierwszy miał miejsce w latach trzydziestych $\mathrm{X}$ wieku, natomiast kolejny przypadał na połowę X wieku. Ostatni z wymienionych posiada korelację w datowaniu upadku grodu Staré Zamký (Brno-Lišeň); Č. Staňa, 200o, Pronikani Boleslava II na Brnènsko ve svètle archeologických objevu, [w:] Premyslovsky stát kolem roku Iooo. Na pamèt knižete Boleslava II. (†7. února 999), ed. L. Polanský, J.D. Třeštík, Praha, s. 197-208, zwł. 207-208.

59 Potwierdza to dokument fundacyjny biskupstwa praskiego, który nie zachował się w oryginale, lecz w kopii podanej przez Kosmasa (Chronica, II, c. 37, s. I36-I40). Według przywileju, jaki Praga uzyskała od cesarza Henryka IV w Io86 roku. Mimo licznych kontrowersji, jakie wzbudza ten dokument (autentyczny pod względem paleograficznym), jego treść odnosząca się do opisu granicy wschodniej diecezji praskiej najlepiej odpowiada realiom historycznym drugiej połowy 
polityki, nadmienić należy, że musiały być znaczne, skoro zapewniły Przemyślidom utrzymanie administracji państwa oraz pozwoliły na stworzenie i utrzymanie licznej, jak na warunki czeskie, drużyny czy zorganizowanie emisji własnej monety ${ }^{60}$. Rozszerzenie terytorium państwa dało także sposobność do kontroli znacznego odcinka głównej arterii handlu międzynarodowego w Europie Środkowej (łączącej Hiszpanię muzułmańską z portami położonymi nad Morzem Czarnym i Kaspijskim (stolica Chazarów, Itil). Przyniosło to spore korzyści materialne i zyski, pozwoliło także na realizację rozległego programu budowlanego ${ }^{61}$ (powstanie grodów, rozbudowa Pragi jako nowego centrum politycznego kraju i siedziby władców ${ }^{62}$, budownictwo sakralne). Praga stała się okazałym ośrodkiem miejskim określonym przez Ibrahima ibn Jakuba jako miasto zbudowane $\mathrm{z}$ kamienia ${ }^{63}$.

Odmienna sytuacja wystąpiła we wschodniej części Kotliny Czeskiej, gdzie znajdowało się księstwo chorwackie rządzone przez Sławnikowiców ${ }^{64}$. Obejmowało ono północno-wschodnią część Kotliny Czeskiej, będąc - jak na warunki czeskie, tworem rozległym pod względem terytorialnym. Początkowo centrum księstwa znajdowało się w grodzie Stará Kouřim. Po jego zdobyciu i zniszczeniu ${ }^{65}$ rolę tę pełniły aż do końca X wieku Libice ${ }^{66}$, które zajmowały rozległy teren, obejmujący 26 hektarów powierzch-

X w. Dyskusję i sporą narosłą literaturę przedmiotu wokół niego omówiła M. Matla-Kozłowska, Pierwsi Przemyślidzi i ich państwo, s. 170-219.

60 Podjęcie emisji własnej monety jeszcze za Bolesława I przyjmują W. Hahn, Herzog Henrich II von Bayern und die Anfänge der böhmischen Münzprägung, „Wiadomości Numizmatyczne” 1977:21, s. I62-167 oraz S. Suchodolski, Spór o początki mennictwa w Czechach i w Polsce, „Wiadomości Numizmatyczne" 42:1998, s. 5-20; Z. Petráň, 1998, První české mince, Praha, s. 92-I04; tenże, 2000, Problematika pražské mincovny za Vidy Boleslava II, [w:] Přemyslovskýstát kolem roku Iooo, s. I47-I54.

61 D. Třšstík, Bohemian iron year, [w:] Europe around the year Iooo, ed. P. Urbańczyk, Warsaw 20oI, s. $427-450$, zwł. s. 437.

62 Tenże, „Veliké mèsto Slovanu jměnem Praha”. Státy a otroci ve středni Evropè v Io. století, [w:] Premyslovsky stát kolem roku Iooo, dz. cyt., s. 49-70.

63 Relacja Ibrahima ibn Jakuba z podróży do krajów stowiańskich w przektadzie al-Bekriego, wstęp, komentarz i przekład T. Kowalski, Monumenta Poloniae Historica, seria II, t. I (PAU Wydawnictwa Komisji Historycznej nr 84), Kraków 1946, s. 49.

64 W historiografii czeskiej w XIX wieku funkcjonowała koncepcja tzw. Państwa Sławnikowiczów, zob. przegląd stanowisk i poglądów - M. Lutovský, Z. Petráň, 2004, Slavnikovici mýtus českého dějepisectví, Praha, s. 28-32. Z polskich badaczy rolę tego tworu terytorialnego najbardziej eksponował J. Dąbrowski, Studia nad początkami państwa polskiego, „Rocznik Krakowski” 1958:34(I). Nowsza historiografia czeska sceptycznie odnosi się do relacji Kosmasa, będącej podstawą dla hipotezy o istnieniu państwa Sławnika i jego następców. Uważa ją za wytwór kronikarza, mający na celu uświetnienia dziejów rodu, z którego pochodził św. Wojciech. Zob. R. Nový, Slavnikovicí $v$ raně středověkých Čechách, [w:] Slavnikovici ve stredověkém pisemnictví, red. R. Nový, J. Sláma, J. Zahová, Praha 1985, s. II-92, zwł. s. 40; J. Sláma, Slavníkovici-významná či okrajova záležitost českých dějin Io. století, „Archeologické rozhledy”, (dalej AR) 1995:47(2), s. I82-224.

65 M. Šolle, Knižeci pohřebiště na Staré Kouřimi, PA 1959:50(2), s. 353-506; tenże, Stará Kouřim a projevy velkomoravské hmotné kultury v Čechách, Praha 1966, s. 227 i n.; R. Turek (Slavnikovici a jejich panství, Hradec Králové I966, s. 82) datował upadek grodu po połowie X wieku.

66 J. Princová-Justová, Knižeci prostrèedí na Slavnikovské Libici ve svètle archeologických objevio, AR I995: 47(2), s. 252-266; J. Princová, J. Mař́ík, Libice nad Cidlinou-atav a perspektivy výzkumu, AR 
ni i składający się z dwóch tarasowych wzniesień położonych nad brzegiem Cidliny. Chroniły dostępu do grodu od strony południowej, natomiast pozostałe strony były zabezpieczone wałami o konstrukcji drewniano-ziemno-kamiennej. W trakcie prac archeologicznych odkryto dobrze zachowane fundamenty kościoła, a na podstawie analizy architektonicznej ustalono, że obiekt ten wskazuje ewidentne oddziaływania architektury ottońskiej. Warto przy tym nadmienić, że świątynia zachowała swój pierwotny kształt (poznany na podstawie zachowanej części fundamentów) w przeciwieństwie do innych, znanych obiektów tego typu w Czechach, datowanych na IX-X wiek, w których elementy pierwotnej zabudowy zostały zniszczone bądź stały się mało czytelne poprzez ich gruntowną przebudowę w dobie gotyku i baroku. Zachowane fundamenty wskazują, że w drugiej połowie X wieku po praskim kościele pw. św. Jerzego świątynia libicka należała ${ }^{67}$ do jednego z najbardziej okazałych kościołów na terenie Czech. Ujawnione podczas prac archeologiczno-architektonicznych analogie do budownictwa sakralnego w Saksonii doby ottońskiej dały podstawę do wysunięcia koncepcji odnośnie kontaktów politycznych Sławnikowiczów z państwem niemieckim w omawianym okresie, jakkolwiek brak na to potwierdzenia w dostępnych przekazach historycznych. Niewiele wiadomo także o czasie i okoliczności, w których miało dojąć do ich nawiązania. Pomiędzy kościołem a pałacem archeolodzy odkryli nekropolię z grobami osób o wysokiej pozycji społecznej ${ }^{68}$, na co wskazują stele nagrobne oraz ułożenie szczątków zmarłych w trumnach, lecz bez wyposażenia grobowego.

$\mathrm{Na}$ terenie podgrodzia w Libicach archeolodzy natrafili na relikty jeszcze innej budowli, o długości 22 metrów; odnośnie jej przeznaczenia wysunięto hipotezę, że był to obiekt mieszkalny dla księży ${ }^{69}$. Wskazuje na to odnaleziony w jego pobliżu stillus oraz fragment naczynia do wody (aquamanile). Na tej podstawie wysunięto hipotezę dotyczącą powstania kościoła na tym terenie podgrodzia w Libicach. Z terenu księstwa chorwackiego Sławnikowiczów wymienić należy kolejną świątynię, jaką był znajdujący się w grodzie Malín kościół pw. św. Jana Chrzciciela - budowla jednonawowa, powstała w drugiej połowie $\mathrm{X}$ wieku, również reprezentująca styl ottońskiej

2006:58(4), s. 643-664, zwł. s. 656-657; J. Košta, Výzkum na akropolí hradiště v Libici nad Cidlinou - současný stav terenni dokumentace výzkumu a evidence fondu, tamże, s. 664-667 oraz s. 665, ryc. I (plan akropolu z zaznaczonymi miejscami, w których przeprowadzono sondy archeologiczne).

67 A. Merhautová, Kostel na Libici, AR 1995:47(2), s. 249-251; M. Lutovský, Z. Petráň, Slavníkovici mýtus českého dějepisectví, s. 69, ryc.; L. Princová, J. Mařík, Libice nad Cidlinou, s. 658.

68 Prowadzący w Libicach wykopaliska R. Turek (Libice. Pohřebšté na vnitřním hradisku, „Sborník narodního muzea. Řada A-Historie” 1976:30, s. 249-316) identyfikował ich jako członków rodu Sławnika, rządzących grodem, jednak z powodu braku stosownej dokumentacji historycznej, jak też metodologicznych uwarunkowań archeologicznych badań stanowiska, pogląd ten traktowany jest przez nowszą literaturę przedmiotu z rezerwą, zob. M. Lutovský, Z. Petráň, Slavníkovici mýtus českého dèjepisectví, s. 7I-72; A. Merhautová, Kostel na Libici, s. 249-25I; J. Justova-Princova, Knižeci prostrédí na slavniíkovské Libici ve svètle archeologických objevư, AR 1996:47(2), s. 245-266.

69 J. Justova, Archeologickývýznam na podhradí slovanského hradištèv vibici nad Cidlinou a jeho zázemí v letech 1980-1984 (předběžná zpráva), AR 1985:37(3), s. 308-318, 357-360; taż, Archeologický výzkum na prèdhradi slovanského hradištè v Libici nad Cidlinou a jeho zázemiv v letech 1985-1989 (prèedběžná zpráva), AR I990:42(6), s. 66I-673, 723-73I. 
architektury sakralnejº ${ }^{7}$ Analogicznie jak w przypadku Libic, gród w Malíne nie uległ zniszczeniu po przyłączeniu tych terenów do państwa Przemyślidów. Powodem mogło być jego dogodne położenie przy ważnym szlaku handlowym o znaczeniu międzynarodowym, którego część przebiegała przez tereny państwa czeskiego.

Charakteryzując rozwój kultury chrześcijańskiej i poziom mentalności religijnej społeczeństwa w Czechach za pierwszych Przemyślidów, należy stwierdzić, że w omawianym okresie był on niski. Za rządów Borzywoja I nowa religia ograniczała się bowiem do wąskiego kręgu osób z najbliższego otoczenia księcia i nie wykraczała poza ośrodki grodowe, przede wszystkim Pragę i Levý Hradec. Powodem tego stanu rzeczy był brak duchownych, mogących prowadzić regularną działalność misyjną. Przybyły wraz z Borzywojem kapłan imieniem Kaich był kapelanem na dworze władcy i jego zadania obejmowały zapewnienie służby liturgicznej rodzinie i wąskiemu kręgowi osób z otoczenia księcia. Ponadto Kaich nie był archiprezbiterem i nie posiadał ani uprawnień, ani współpracowników, by prowadzić działalność misyjną.

Poza wymienionym kapłanem w źródłach brak informacji o działalności w tym czasie innych duchownych na terenie Czech. Warto też nadmienić, że teren podległy bezpośrednio Borzywojowi był niewielki i ograniczony jedynie do plemienia Czechów. Ponadto nawet wśród współplemieńców książę nie znalazł akceptacji dla swojej decyzji o przyjęciu nowej religii. Jest także wątpliwym, aby kościół morawski prowadził energiczną chrystianizację ludności Kotliny Czeskiej, zwłaszcza że tamtejsze arcybiskupstwo odczuwało braki kadrowe po śmierci Metodego oraz wygnaniu z terenu państwa (wielko-)morawskiego jego uczniów i współpracowników. Warto też pamiętać, że po 886 roku działał tylko jeden znany w źródłach biskup, Wiching, natomiast stanowisko arcybiskupa pozostawało aż do końca IX wieku nieobsadzone. Po wyjeździe Wichinga sytuacja organizacji kościelnej w państwie Świętopełka I i Mojmira II uległa pogorszeniu. Dopiero w 899 roku zostało reaktywowane arcybiskupstwo morawskie wraz z trzema sufraganiami.

W swojej kronice Kosmas enigmatycznie nadmienił o osiągnięciach Borzywoja I w zakresie chrystianizacji i organizacji kościoła w Czechach $^{71}$. Dopiero po przejściu plemion osiadłych w Kotlinie Czeskiej pod zależność polityczną i kościelną Bawarii zaistniały korzystniejsze warunki dla prowadzenia działalności chrystianizacyjnej ${ }^{2}$. Najstarsza łacińska wersja (bawarska) pierwszej starosłowiańskiej legendy o św. Wacławie i Ludmile wymienia kapłana o imieniu Paweł, określonego jako maior pres-

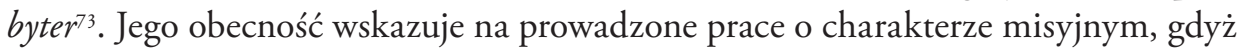
archiprezbiter miał uprawnienia do nauczania, a przede wszystkim kierował pracami podległych mu duchownych, jemu też podlegała szkoła, w której przygotowywano kandydatów do stanu duchownego. Był najważniejszą osobą po biskupie na terenie,

70 K. Benešovská-Fišerová, Sakrálna architektura v Malině u Kutné Hory, „Sborník narodního muzea. Řada A-Historie" 1986:39, s. 69-77.

71 Kosmas, Chronica, I, c. I5, s. 35 .

72 Ann. Fuld., a. 895, s. I26.

73 Crescente fide, s. 184. 
gdzie prowadzona była działalność misyjna. Założenie archiprezbiteratu w omawianym okresie było dziełem biskupa ratyzbońskiego Tuto (894-930), który miał także dokonać symbolicznych postrzyżyn młodego Wacława. W okresie rządów książąt Spitygniewa I i jego brata, Wratysława I, datować należy powstanie kolejnych kościołów na terenie domeny Przemyślidów, a Diffundente sole, źródło powstałe w kręgu tradycji związanej ze św. Wacławem, bardzo wysoko ocenia dokonania pierwszego z wymienionych władców w zakresie wspierania nowej religii (budowa kościołów, gromadzenie kapłanów i kleryków), powielając jego zasługi w odniesieniu do następcy ${ }^{74}$.

Legendy związane z osobą św. Wacława przynoszą informację o jego edukacji w szkole znajdującej się w Budeču, gdzie przebywał młody książę na dworze swojej babki. Ludmiły, która po śmierci Borzywoja osiadła w tym grodzie i wspierała działających w kraju duchownych, których grupa przebywała w Budeču. Problemem była stosunkowo skromna liczba kapłanów działających przy istniejących już świątyniach, co znacznie ograniczało prowadzenie aktywnej i szerszej chrystianizacji wśród mieszkańców Kotliny Czeskiej. O pozyskanie kolejnych kapłanów zabiegał także Wacław I (92I-935). Jedno ze źródeł informuje, że pochodzili oni z Bawarii, Szwabii i innych krajów, ponadto książę dokładał starań, dbając o zapewnienie ksiąg niezbędnych do celebrowania nabożeństw ${ }^{75}$.

Jednak rozwój chrystianizacji pozostawał w ścisłej zależności od stopnia, w jakim Przemyślidzi uzyskiwali władzę zwierzchnią nad pozostałymi plemionami na terenie Kotliny Czeskiej. Dlatego aż do lat trzydziestych X wieku chrześcijaństwo nie przekraczało domeny Przemyślidów, a kolejna faza jego rozprzestrzeniania przypadała na rządy Bolesława I i jego następcy, Bolesława II. Procesy związane z przemianami, jakie przyniosła nowa religia, uległy przyspieszeniu za pierwszego z wymienionych władców, który przystąpił do likwidacji odrębnych księstw, jedynie nominalnie uznających zwierzchność Przymyślidów. Rezultaty wieloletnich badań archeologicznych ${ }^{76}$ ukazują wyraźną zmianę w dotychczasowej topografii grodów w połowie X wieku. Dawne, wywodzące się jeszcze z doby plemiennej (pogańskiej), zostały zastąpione nowymi, związanymi z Przemyślidami ${ }^{77}$.

Miarę postępu zasięgu nowej religii może stanowić kryterium liczby powstałych kościołów, znacznie wyższej w porównaniu do IX wieku. Charakteryzując rządy Bolesława II, Kosmas nadmienił o powstaniu wówczas aż 20 nowych świątyń ${ }^{78}$.

74 Diffundente sole, c. 9, s. 283: (...) fundator existitit ecclesiarum Dei, congregator sacerdotum clericorumgue perfectum in fide Christi (...).

75 Legenda Christiani, c. 6, s. 56.

76 J. Slůma, Stredni Čechy III, s. 80-8I. Interesującą wzmiankę dotyczącą polityki Bolesława I wobec innych książąt z Kotliny Czeskiej podał Widukind (Rerum gestarum Saxonicarum, II, c. 3, s. 69) pisząc, że gród jego przeciwnika po zdobyciu został zniszczony. Nie można wykluczyć, że akcje te były skoordynowane z planami księcia, kiedy miała miejsce wojna z królem Ottonem I.

77 Tylko w przypadku Libic i Malina odstąpiono od tej zasady. Zachowanie przez nie dotychczasowego znaczenia po przyłączeniu do państwa Bolesława I wynikało przede wszystkim z położenia przy najważniejszym szlaku handlowym, którego kontrola przynosiła Przemyślidom znaczne korzyści.

78 Kosmas, Chronica, I, c. 24, s. 46. Liczba podana przez kronikarza jest niewiele mniejsza aniżeli znane i potwierdzone archeologicznie kościoły (24) w państwie (wielko-)morawskim. 
Badacze dość ostrożnie traktują powyższy przekaz ${ }^{79}$, nie można bowiem wykluczyć, że część z nich była dziełem poprzedniego władcy, Bolesława I. Były to wszystko obiekty murowane, dlatego część autorów przypuszcza, że poza nimi istniały drewniane obiekty architektury sakralnej (kościoły, kaplice), jednak w dotychczasowych badaniach archeologicznych ich pozostałości (dołki po słupach, resztki konstrukcji) są rzadko spotykane ${ }^{80}$. Problemem trudniejszym aniżeli samo wzniesienie budowli było jej wyposażenie w sprzęt i księgi liturgiczne, a przede wszystkim zapewnienie odpowiedniej liczby księży dla sprawowania służby Bożej. Znajduje to potwierdzenie w relacji Kosmasa dotyczącej wyświęcenia przez biskupa Ditmara wielu kościołów zaraz po objęciu diecezji ${ }^{81}$. Nie można jednak wykluczyć, że część z nich była dziełem Bolesława I, który ze względu na okoliczności, w jakich objął władzę, w historiografii czeskiej nie cieszył się dobrą opinią. Biskup diecezję objął w 976 roku i kierował nią jedynie siedem lat, a - uwzględniając tempo realizacji budowy jak też wyposażenie kościoła i zapewnienie mu obsady kapłańskiej, należy przychylić się do opinii, że część z podanej przez Kosmasa liczby świątyń, jaką kronikarz przypisał inicjatywie i fundacji Bolesława II, powstała najprawdopodobniej jeszcze za rządów Bolesława I. W większości wzmiankowane przez kronikarza świątynie stanęły przede wszystkim w obrębie grodów znajdujących się w środkowej części Kotliny Czeskiej, czyli na obszarze domeny Przemyślidów.

Warto wskazać na inną jeszcze przesłankę, przemawiającą za przypisaniem części powstałych w Czechach kościołów w okresie rządów Bolesława I, a odnoszącą się do sfery gospodarczej. Za wymienionego księcia na skutek podboju ziem południowopolskich, nastąpił znaczny wzrost terytorialny państwa co zapewniło czerpanie znacznych dochodów tytułem łupów i trybutów a przede wszystkim kontrolę części ważnego szklaku transkontynentalnego w kierunku Rusi i portów nad Morzem Czarnym. Handel z Rusią był zyskowny, przynosząc środki, jakie władca mógł przeznaczyć także na realizację programu budownictwa sakralnego. Utrata nabytków terytorialnych, jaka miała miejsce w latach 989-990, ograniczyła znacznie możliwości realizacji ambitnego programu budowlanego w państwie.

Wymieniona przez Kosmasa liczba kościołów nie znajduje potwierdzenia w nowszych badaniach archeologiczno-architektonicznych obejmujących główne grody czeskie w X wieku. Do grupy najstarszych i udokumentowanych obiektów sakralnych zaliczyć należy te znajdujące się w Pradze (NPM, bazylika św. Jerzego, rotunda św. Wita), Levým Hradcu (św. Klemens), Budeču (św. Piotra), Tetínie, Starej Boleslavi (śś. Kosmy i Damiana) oraz w Libicach i Malíne (położone w domenie Sławnikowiców).

79 M. Matla (Chrystianizacja Czech, [w:] Chrystianizacja „Mtodszej Europy”, red. J. Dobosz, J. Strzelczyk, M. Matla (UAM seria Historia nr 228), Poznań 20I6, s. 97) szacuje, że w ciągu stulecia, jakie upłynęło pomiędzy panowaniem Borzywoja I a Bolesława II, wzniesiono w Czechach około I4 kościołów.

80 O. Kytlicová, Slovanské pohřebiště v Brandýsku, Pam. Arch. 1968:59(I), s. 93-248 wzmiankuje o reliktach drewnianego kościoła datowanego na okres rządów św. Wacława. 
Obecnie chrystianizację traktujemy jako proces długotrwały, który rozpoczął się od aktu chrztu księcia oraz jego najbliższego otoczenia i drużynników, a następnie był stopniowo rozszerzany na kolejne grupy społeczne i rejony kraju. Proces ten pozostawał w zależności od stopnia integracji państwa i postępów w umacnianiu władzy książęcej. Natomiast znacznie wolniej postępowały zmiany w mentalności ludzi, przyzwyczajenie do nowych norm, obyczajów i sposobów postępowania w życiu codziennym, zgodnie z nakazami nowej religii. Według autora Legendy Krystiana książę Wacław I wymierzał chłostę tym spośród możnych, którzy nie stosowali się do nowych zasad ${ }^{82}$. Aby zachęcić ludność do uczestnictwa w niedzielnej mszy świętej, książę Bolesław I zezwolił na organizowanie targowisk w dni świąteczne i w niedzielę $e^{83}$. Do rzadkości należała postawa księcia Wacława I, który naśladował życie ewangeliczne w stopniu takim, jak czynili to duchowni ${ }^{84}$. O tym, jak długo utrzymały się dawne zwyczaje i z jakim trudem duchowni wprowadzali w Czechach zasady chrześcijańskiego życia w X wieku, świadczą relacje dotyczące działalności drugiego biskupa praskiego - Wojciecha. Był on zrażony oporem ze strony możnych i mieszkańców Pragi. Zdecydował się nawet na opuszczenie diecezji ${ }^{85}$.

Nie tylko środowisko wiejskie ${ }^{86}$ wykazywało tradycyjny konserwatyzm, na przykład w zakresie zwyczajów funeralnych. Jak wskazują badania archeologiczne, jeszcze długo po chrystianizacji praktykowano zwyczaj wyposażania grobów w przedmioty, jakich zmarli używali za życia ${ }^{87}$. Dla możnych była to przede wszystkim okazja do zamanifestowania zajmowanej pozycji społecznej. Ponadto ich rola w strukturach władzy i poparcie, jakiego udzielał im książę, powodowały, że grupa ta długo nie była skłonna do stosowania się do nowych zasad w tym zakresie, jak też w odniesieniu do moralności i prawa kościelnego (nieprzestrzeganie kościelnych regulacji odnośnie stopnia pokrewieństwa przy zawieraniu związków małżeńskich). Relikty dawnych praktyk i zwyczajów funeralnych utrzymały się w Czechach w X-XI wieku. Ciekawe świadectwo przynoszą

82 Legenda Christiani, c. 6, s. 60.

83 Kosmas, Chronica, II, c. 4, s. 87.

84 Ideał monastyczny w duchowości Wacława I przedstawiła A. Kuźmiuk-Ciekanowska, Święty i historia, s. I69-I85, I9I-20I. Książę reprezentował nowy jej typ w odniesieniu do ludzi świeckich $\mathrm{X}$ wieku, dających w pełni przykład życia zgodnego z nakazami Ewangelii. Wacław był typem świętego władcy.

85 S. Adalberti Pragensis episcopi et martyris vita prima, ed. J. Karwasińska, Monumenta Poloniae Historica, series nova VI.I, Warszawa 1962, c. I2, s. I8 i c. I3, s. I9 zostały wymienione główne grzechy, jakich dopuszczali się Czesi - wielożeństwo, nieprzestrzegania celibatu przez duchownych a także handel ludźmi (niewolnicy): S. Adalberti Pragensis episcopi et martyris vita altera auctore Brunone Querfurtensi, ed. J. Karwasińska, Monumenta Poloniae Historica, series nova VI. 2, Warszawa I969, c. I5 s. I8 oraz c. I6, s. I8-I9; P. Sommer, Duchovni svět raně strédověkè české laické společenství, [w:] Svatý Vojtěch, Čechové a Europa, red. D. Třeštík, J. Žemlička, Praha I998, s. 133-I66.

86 Kosmas, Chronica, III, c. I, s. I6I, charakteryzując pod tym kątem społeczeństwo wiejskie w początku XII wieku, określił je jako semipagani. W odniesieniu do interpretacji materiałów archeologicznych zob. Z. Krumphanzlova, Chronologie pohřebniho inventáre vesnických hribitovů 9.-II. Věku v Čechách, Pam. Arch. I974:65(I), s. 34-39 (aspekty historyczne).

87 Z. Krumphanzlova, Svédectví naboženského synkretismu na pohřebištich diby hradištni v Čechách, AR 1990: 42(3), s. 362-368. 
dekrety Brzetysława I (IO39) w odniesieniu do sfery obyczajowej, jak zakaz wielożeństwa, nakaz zawierania ślubów w kościele, kary za zerwanie związków małżeńskich, aborcję, prostytucję, pijaństwo, zakaz organizowania targów i pracy w niedzielę i dni świąteczne oraz przestrzeganie zaleceń kościelnych dotyczących obowiązku pochówku zmarłych na $\mathrm{cmentarzach}^{88}$. Pomimo, że jego początki sięgają połowy IX wieku, to jeszcze wiek później chrześcijaństwo w Czechach nadal było powierzchowne, żeby nie powiedzieć surowe. Należy zaznaczyć, że ograniczało się do głównych ośrodków grodowych, a brak odpowiedniej liczny kapłanów powodował, iż znaczna cześć ówczesnej ludności miała ograniczony dostęp do świątyń i uczestnictwa w praktykach religijnych. Jedną z przyczyn był brak własnego biskupstwa, co znacznie utrudniało prowadzenie chrystianizacji w sposób systematyczny i planowy, nie mówiąc już o kształceniu kandydatów do stanu kapłańskiego. Przede wszystkim odczuwany był niedostatek duchownych, o czym informuje żywot św. Wacława, mówiący o staraniach, jakie podejmował ten książę dla pozyskania kapłanów do pracy wśród Czechów ${ }^{89}$.

\section{Biskupstwo praskie}

Historia utworzenia diecezji praskiej nie jest dokładnie znana. Niektórzy badacze dopatrywali się jej początków już za księcia Wacława I. Jedną z pierwszych jego decyzji po objęciu rządów było przeniesienie ciała Ludmiły z Tetina do Pragi, a także budowa kościoła pw. św. Wita ${ }^{90}$. Zabiegi związane z uzyskaniem zgody Stolicy Apostolskiej oraz Ratyzbony, aby utworzyć własną diecezję, były procesem czasochłonnym i złożonym, wymagającym uzgodnień i współdziałania ze sobą na różnych szczeblach władzy świeckiej oraz duchownej. Starania w zakresie utworzenia własnego biskupstwa obecnie przypisuje się księciu Bolesławowi I, jednak z nieznanych przyczyn zamiar ten nie doczekał się realizacji. Relacjonując okoliczności erygowania biskupstwa praskiego Kosmas przypisał inicjatywę i zasługi w tym zakresie Bolesławowi II, co stanowiło

88 Kosmas, Chronika, II, c. 4, s. 85-90 zwyczaj ten miał dawniejszą genezę i wywodził się z okresu rządów księcia Bolesława I, który zezwolił na organizowanie w ten dzień targów, co miało przyciągnąć wiernych do udziału w mszy świętej. Odnośnie dekretów Brzetysława I zob. V. Vaněček, Prameny k dějinám státu a práva v Československu (chrestomatie), č. I: Do husitského revolučneího hnutí, Praha 1957, s. 3I-37; tenże, Nový text (varianta) dekretú Břetislavových z r. 1039, "Slavia Antiqua” 1952:3, s. I3I-I33; B. Krzemieńska, Břetislav I, Praha 1986 (według indeksu); G. Labuda, Dekrety Brzetystawa I, [w:] Stownik starożytności stowiańskich, 1962, t. I(2), s. 334-335; J. Žemlička, Čechy $v$ době knižecí (I034-II98), Praha 1997, s. 21, 23, 203-204; Z. Krumphanzlová, Počátký křestanství $v$ Čechách, 406-456; taż, Die austattung der Burgwallzeitfriedhöfe in Böhmen und Imre rituelle Bedeutung, „Vznik a počatký Slovanů” 1972, 7, s. 179-206; taż, Chronologie pohřebního inventáre vesnických hřbitovĩ, s. 34-IIO; Z. Váňa, K současnému stanu studia slovanského pohanství, Pam. Arch., 1985:76(I), s. 228-250.

89 D. Třeštík, Počatký Přemyslovců, s. 365-367. Tylko nieliczni spośród działających w państwie Przemyślidów w $\mathrm{X}$ wieku duchownych znani są z imienia, zob. P. Sommer, D. Třeštík, J. Žemlička, Bohemia and Moravia, s. 229.

90 Pogląd ten wysunął V.V. Tomek (I863), lecz nie zyskał on akceptacji w nowszej historiografii czeskiej, por. D. Třeštík, Počatký Přemyslovcư, s. 409; M. Matla, Chrystianizacja Czech, s. 99 przyp. 87. 
dopełnienie wizerunku tego księcia jako władcy idealnego, dbałego o zbawienie poddanych, troskliwego dla Kościoła. Służył temu zabieg przesunięcia daty śmierci Bolesława I z 972 na 967 rok, dzięki czemu kronikarz inicjatywę wysłania poselstwa do Rzymu mógł „przypisać” jego następcy. Niewątpliwie poważną przeszkodą okazała się postawa biskupa Ratyzbony, Michała (†972), któremu podlegały Czechy od końca IX wieku, a który nie popierał idei utworzenia odrębnego biskupstwa, bo wiązało się to z uszczupleniem terytorium własnej diecezji. Sytuacja uległa zmianie dopiero za kolejnego biskupa ratyzbońskiego, Wolfganga.

Proces związany z uzyskaniem stosownej zgody Stolicy Apostolskiej poprzedziły negocjacje z Ratyzboną, Salzburgiem i Moguncją odnośnie kwestii jurysdykcji kościelnej nowej diecezji, wymagana była także aprobata ze strony cesarstwa niemieckiego. Na zjeździe w Kwedlinburgu w 973 roku zapadła korzystna dla planów czeskich decyzja dotycząca utworzenia nowego biskupstwa. Ratyzbona uzyskała rekompensatę za utracone terytorium Czech, dokonano przy tym zmiany przynależności metropolitalnej nowej diecezji. Proces ten należy datować na lata 973-976. Ważną rolę w staraniach w Rzymie odegrała siostra Bolesława II, Mlada-Maria, będąca zakonnicą w klasztorze Niedermünster (późniejsza ksieni klasztoru pw. św. Jerzego w Pradze), która wzięła udział w poselstwie wysłanym do papieża w 967-968 roku, w celu uzyskania zgody na tworzenie w Czechach biskupstwa ${ }^{91}$. Ona to - według relacji Kosmasa, przywiozła bullę papieża Jana XIII dotyczącą utworzenia biskupstwa praskiego (973). Dlatego należy przychylić się do stanowiska tych badaczy, którzy reprezentują pogląd, że działania mające przynieść Czechom własne biskupstwo rozpoczęły się jeszcze za rządów Bolesława $\mathrm{I}^{92}$.

Okoliczności utworzenia biskupstwa w Pradze nie są do końca znane, nadal występuje sporo kwestii spornych. Oryginał dokumentu fundacyjnego nie zachował się. Jego treść znana jest w wersji zamieszczonej przez Kosmasa, a opartej na przywileju, jaki biskupstwo praskie otrzymało od cesarza Henryka IV w Ratyzbonie, 24 kwietnia I086 roku. Dokument ten, posiadający liczną literaturę przedmiotu, budzi wątpliwości w kwestii autentyczności ${ }^{93}$. Inicjatorem jego wystawienia był biskup praski Jaromir-Gebhard, który dążył do przyłączenia do swojej diecezji biskupstwa ołomunieckiego, stąd w tekście znajdujemy dane pozostające w sprzeczności z realiami historycznymi. Dobrze to ilustruje opis granicy wschodniej biskupstwa praskiego. Według dokumentu z 1086 roku erygowanie biskupstwa miało miejsce za rządów cesarza Ottona I (973), a pierwszy biskup Detmar otrzymał sakrę w Brumath pomiędzy 3 a I6 stycznia 976 roku.

91 Odnośnie podstawowej literatury dotyczącej tej kwestii zob. D. Třeštík, Bohemia’s iron year, [w:] Europe around year 1000, ed. P. Urbańczyk, Warsaw 2002, s. 439, przyp. 21.

92 P. Charvát, The emergence of the Bohemian state, (East Central and Eastern Europe in the Middle Ages, 450-I450, vol. 13), Leiden-Boston 2010, s. I75-176.

93 Zob. uwagę M. Wojciechowskiej do polskiego przekładu Kosmasa kronika Czechów, przekład, wstęp i komentarze M. Wojciechowska, Warszawa 1968, s. I43, przyp. 40. Wskazuje na to tekst arengi, zawierający w kronice brzmienie w formie używanej w XI/XII wieku. 
Rozpatrując genezę powstania biskupstwa, G.Labuda zwrócił uwagę na informację zamieszczoną w Roczniku Traski, w której rok 974 wymieniony jest jako data powstania biskupstwa praskiego ${ }^{94}$. Źródło to powstało w XIV wieku, lecz jego autor korzystał z dawnego rocznika krakowskiego, zawierającego szereg informacji pochodzących ze źródeł czeskich. Ich śladem jest podanie imienia pierwszego biskupa praskiego oraz Dobrawy, która miała przyczynić się do powstania nowego biskupstwa. Z dotychczasowych badań wynika, że w latach 973-976 doszło ostatecznie do rozstrzygnięcia spornych kwestii prawno-kościelnych związanych z funkcjonowaniem w praktyce nowej diecezji. Ukazuje to trudności, na jakie napotkał plan utworzenia własnego biskupstwa. Innym powodem opóźnienia był kryzys w dotychczasowych relacjach czesko-niemieckich, powstały po śmierci Ottona I na tle zabiegów księcia bawarskiego (Henryka) o tron, w czym uzyskał on wsparcie ze strony Bolesława II.

Nowo powstała diecezja praska została podporządkowana metropolii w Moguncji, a nie w Salzburgu. Pierwszym biskupem praskim był pochodzący z Saksonii mnich z klasztoru Nova Corbea, Ditmar (976-983), kolejnymi natomiast: Wojciech (982/3-997), Thiedag (998-IOI7) mnich korwejski, Ekkehard (IOI7-IO23), Hizzo (I023-IO3O) i Sewer (IO3O/3I-IO67). Obok działającego w Pradze żeńskiego klasztoru benedyktynek, w ostatnim dziesięcioleciu X wieku powstały także klasztory męskie w Brzewnowie w 992-993 roku (inicjatorem był biskup Wojciech Sławnikowic) oraz w Ostrowie przy Davle (fundacja, którą zainicjował Bolesław II w 999 roku, lecz ostatecznie zrealizowana została przez księcia Bolesława III).

\section{Biskupstwo i organizacja kościelna na Morawach w X wieku}

W państwie Przemyślidów w drugiej połowie X wieku znajdowała się kolejna diecezja - morawska, z siedzibą w Ołomuńcu, lecz jej dzieje w omawianym okresie pozostają bardziej złożone. Gdy bierze się pod uwagę fakt, że Morawy były schrystianizowane już w pierwszej połowie IX wieku, a w okresie wielkomorawskim posiadały własne arcybiskupstwo, pojawia się pytanie: czy w działalności biskupstwa morawskiego w X stuleciu mamy do czynienia z jego odnowieniem czy też fundacją? W podjętych przez Przemyślidów staraniach o utworzenie własnego biskupstwa, okolicznością sprzyjającą było arcybiskupstwo morawskie z okresu działalności Metodego, które zostało reaktywowane przez papieża Jana IX w 900 roku. Działalność tej prowincji nie trwała jednak długo, z powodu upadku państwa Mojmira II (przed 907), lecz możemy zauważyć przetrwanie wielkomorawskiej tradycji kościelnej95, czego przykładem jest biskupstwo w Ołomuńcu określane jako „morawskie”.

Dzieje organizacji kościelnej na Morawach po upadku Wielkich Moraw należą do bardzo mało poznanych. Jeszcze przed bitwą pod Bratysławą (907) reaktywo-

94 G. Labuda, Czeskie chrześsijaństwo na Ślasku i w Matopolsce w X i XI wieku, [w:] Chrystianizacja Polski potudniowej, red. J. Wyrozumski, Kraków 1994, s. 73-98, zwł. s. 94-96 (Exkurs II).

95 Z. Fiala, Dva kritické príspevky ke starým dějinám českým, „Sborník historický” 1962: 9, s. 5-65, zwł. s. 56-63. 
wana została organizacja kościelna - arcybiskupstwo wraz z trzema sufraganiami, których siedziby należy (z uwagi na to, że część terytorium państwa po śmierci Świętopełka I została utracona) lokalizować na terenie Moraw i zachodniej Słowacji. Z ośrodków morawskich znany jest dobrze Ołomuniec, a siedziby pozostałych są nieustalone. Należy przy tym zaznaczyć, że wysuwane w literaturze przedmiotu sugestie odnośnie powstania w okresie istnienia państwa (wielko-)morawskiego biskupstw w Pradze, a nawet w Krakowie, są pozbawione podstaw źródłowych ${ }^{6}$. Ich autorzy powołują się na bullę papieża Jana IX z 899 roku, dotyczącą ustanowienia arcybiskupa i trzech jego sufraganów ${ }^{97}$. Jednak z listu-protestu, jaki biskupi bawarscy wystosowali do papieża, kwestionując powyższą decyzję, wynika wyraźnie, że nowa organizacja kościelna obejmowała swoim zasięgiem tylko teren Moraw, które w okresie przedcyrylometodiańskim znajdowały się w jurysdykcji kościelnej biskupstwa passawskiego ${ }^{98}$.

Nowo reaktywowana metropolia morawska nie przetrwała długo. Stało się tak z powodu upadku państwa Mojmira II (około 905-907), do czego przyczyniła się zmiana sytuacji politycznej i militarnej w regionie spowodowana wojną domową, której podłożem była rywalizacja o władzę w państwie oraz wybuch nowego konfliktu bawarsko-madziarskiego ${ }^{99}$. W ostatnim z wymienionych wydarzeń brali udział Morawianie, których książę opowiedział się po stronie króla wschodniofrankijskiego. Finałem trwających zmagań była decydująca dla całego regionu bitwą pod Bratysławą (907), zakończona rozgromieniem wojsk bawarskich ${ }^{100}$. Brak informacji w źródłach o udziale w niej Morawian wskazuje na to, że państwo Mojmira II przestało odgrywać ważniejszą rolę w strefie środkowego Dunaju bądź też upadło. W następstwie odniesionego zwycięstwa doszło do najazdów koczowników na tereny położone w dorzeczu

96 Przegląd stanowisk H. Łowmiański, Początki Polski, s. 493-515; L.E. Havlík, Kronika o Velké Moravě, Brno I987, s. 210; J. Steinhübel, Die Großmährishen Bistumer zur Zeit Mojmirs II, „Bohemia” 1996: 37(I), s. I-22, zwł. s. Io, przyp. 39.

97 Magnae Moraviae fontes historici, ed. L.E. Havlík et al. (dalej MMFH), 3, nr IO9, s. 233-234.

98 MMFH 3, nr I09, s. 233-244, zwł. s. 234-236.

99 Ch. Bowlus, Franks, Moravians, and Magyars: The Struggle for the Middle Danube, 788-907, Philadelphia 1995, s. 235-267; I. Panic, Początki Wegier. Polityczne aspekty formowania się państwa i spoteczeństwa węierskiego w końcu IX $i$ w pierwszej potowie X wieku, Cieszyn 1995, s. 66-78; D. Třeštík, Pad Velké Moravy, [w:] Typologie raně feudálních slovenských států, Praha 1987, s. 4I-62; J. Steinhübel, Mad'ari, Slovania, Bavori a Sasi v rokach 896-933, [w:] Bitka pri Bratislave v roku 907 a jej význam pre vývoj stredného Podunajska, red. T. Štefanovíčová, D. Hulínek, Bratislava 2008, s. 39-50, zwł. s. 39-4I.

100 Ann. Iuvavenses maximi, ed. H. Bresslau, MGH Scriptores 30(2), Havnnoverae 1932, a. 907: Bellum pesssimum fecie ad Brezalauspurc IIII nonas Iulii; opis przebiegu bitwy przedstawił bawarski kanonik i humanista Jan Aventyn, wykorzystując liczne źródła, które nie zachowały się do naszych czasów, zob. jego dane do rekonstrukcji jej przebiegu M. Vyvíjalová, Bitka pri Bratislave roku 907 (príspevok ku kritickému prehodnateniu pramenov), „Študijné zvesti Archeologického Ústavu Slovanskej Akadémie Vied" 1985:2I, s. 22I-247; R. Marsína, Bitka pri Bratislave v roku 907 zpohladu historických prameňev, [w:] Bitka pri Bratislave v roku 907, s. 19-23. O roli tej bitwy zob. B. Pintérová, Bitka pri Bratislave (907) vo svetle slovenskej a madjarskej historiografie, tamże, s. 25-32; L. Veszprémy, Boj pri Bratislave (907) v madjarskej historiografii, [w:] tamże, s. 33-37. 
Morawy i Dyi, w rezultacie których destrukcji uległy główne centra grodowe położone w południowej i środkowej części kraju. Wskazują na to materiały archeologiczne pochodzące z Mikulczyc (między innymi rejon trzeciego kościoła, tzw. bazyliki), Sadów czy Pohanska koło Břeclavia ${ }^{\text {IoI }}$. Osadnictwo na tych terenach nie uległo jednak załamaniu, jakkolwiek bliskie sąsiedztwo plemion madziarskich oraz ich częste najazdy na tereny Niemiec środkowych i północnych mogły odbywać się z wykorzystaniem terenów Moraw. Odnosiło się to zwłaszcza do akcji militarnych, jakie koczownicy podjęli w latach 924-925 i w 933 roku. Nie wyklucza się też możliwości czasowego zajęcia przez Madziarów części terytorium Moraw bądź nawet pobierania trybutu ${ }^{102}$.

Brak organizacji państwowej utrudnił niewątpliwie działalność niedawno reaktywowanej organizacji kościelnej, lecz niekoniecznie musiało dojść do zaprzestania jej działalności w wymiarze lokalnym. Nie możemy również wykluczyć przetrwania niektórych z odnowionych w 899 roku biskupstw, choć w zaistniałych warunkach zakres ich działalności byłby ograniczony ${ }^{103}$. Warto zaznaczyć, że skala zniszczeń po najazdach madziarskich spowodowała zmiany w dotychczasowej strukturze osadnictwa. W miejsce starych centrów grodowych i aglomeracji miejskich powstały nowe ośrodki. Jednym z nich był położony na północy Moraw Ołomuniec ${ }^{104}$, który - jak ukazują to znaleziska archeologiczne, utrzymywał kontakty z południową i środkową częścią Moraw, gdzie nadal funkcjonowały ośrodki wytwórczości i handlu. Obecnie wśród archeologów przeważa pogląd o regresie, lecz nie o głębokiej destrukcji osadnictwa na Morawach w okresie powielkomorawskim, będącym skutkiem najazdów plemion węgierskich ${ }^{\text {105 }}$.

101 Z. Měrínský, Morava v Io. století ve světle archeologických nálezu, Pam. Arch., I986:77(I), s. 34-42, 52-63; tenże, Morava v I0. a na počátku II, [w:] Bitka pri Bratislave v roku 907, s. 79-II2; J. Macháček, M. Vihoda, Dolni Podyjí mezi velkou a premyslovskou Moravou. Archeologicko-historická interpretace výsledku interdisciplinárnohi výskumu z let 2007-20I2, AR 2013:65(4), s. 879-894, zwł. s. 879-880 (osadnictwo w rejonie dworu możnowładczego w Pohansku).

102 L.E. Havlík, Morava v 9.-Io. století, (Studie ČSAV, č. 7), Praha 1978, s. IOo. Nie można wykluczyć zajęcia przez Madziarów części terytorium poprzez kontrolę miejsc o znaczeniu strategicznym, analogicznie, jak miało to miejsce na terenie Słowacji południowo-zachodniej w omawianym okresie.

103 M. Matla (Chrystianizacja Czech, s. IO2) sceptycznie ocenia możliwość utrzymania się organizacji kościelnej na Morawach w omawianym okresie, przede wszystkim z powodu braku centralnej władzy państwowej, której w żaden sposób nie mogły zastąpić lokalne ośrodki. Natomiast L.E. Havlík (Morava v 9.-Io. století, s. IOO-IOI) nie wykluczał możliwości przetrwania w pierwszej połowie $\mathrm{X}$ wieku organizacji państwowej w ograniczonej formie. Należy jednak zwrócić uwagę na powstanie w bezpośrednim sąsiedztwie Moraw silnych i rozwijających się państw: księstwa Przemyślidów w Czechach oraz Madziarów w Panonii, dla których teren Moraw stanowił dogodny cel ekspansji.

104 J. Bláha, Archeologické poznatký k vývoji a Uznamu Olomouce vobdobi Velkomoravské riše, [w:] Velka Morava mezi Výhodem a Západem, ed. L. Galuška, P. Kouřil, Z. Měř́nský (Spisy Archeologického Ústavu AV ČR I7), Brno 200I, s. 4I-68.

105 Z. Měŕnský, Morava v Io. století ve svètle archeologických nálezu, s. 20, mapka I, 34-52 (dane dla I połowy X wieku), 52-63 (sytuacja osadnictwa na terenie południowej części Moraw). Przykłady pochodzące z terenu Słowacji południowo-zachodniej z omawianego okresu wskazują, że koczownicy zajmowali miejsca o znaczeniu strategicznym, pozwalającym im na kontrolowanie nowych ziem. O intensywnym rozwoju osadnictwa Madziarów (o charakterze niewojskowym), w oparciu o ślady archeologiczne możemy mówić dopiero na przełomie X/XI wieku. N. Profantová, 
Dla koncepcji istnienia przed 976 rokiem organizacji kościelnej na Morawach podstawę stanowi kompilacja powstała na początku XV wieku, w której dla interesującego nas okresu występuje aż dwóch biskupów: Jan (9I6) i Sylwester. Ostatni z wymienionych godność episkopalną sprawował przez dziewiętnaście lat, a po jego śmierci nastąpił blisko dziesięcioletni vacat na tronie biskupim ${ }^{106}$. Do tekstu Granum nawiązał i rozbudował zaczerpnięte z niego dane kanonik i humanista ołomuniecki, Augustyn Käsenbrat († I5I3). Z uwagi na wyraźne związki z katalogiem biskupów ołomunieckich z początku XV wieku, wiarygodność tekstu duchownego z Ołomuńca jest poddawana w wątpliwość. W kwestii przetrwania tradycji kościelnej po upadku państwa Mojmira II wśród badaczy występują rozbieżne stanowiska, od akceptacji utrzymania ciągłości funkcjonowania organizacji kościelnej w głąb dziesiątego stulecia ${ }^{107}$ aż po jej negację $e^{108}$. W 976 roku na synodzie w Moguncji wraz z nowo konsekrowanym biskupem praskim (Ditmarem) występował nieznany z imienia episcopus Moravienses ${ }^{109}$. W oparciu o listy Pilgrima część badaczy opowiada się za odnowieniem biskupstwa dla Moraw z siedzibą w Ołomuńcu, jednocześnie zwracając uwagę na opanowanie przez księcia Bolesława I terenów położonych na północy kraju ${ }^{\text {Iо }}$. Władztwo Przemyślidów na Morawach rozwijało się intensywnie, tak, iż za Bolesława II cały kraj znalazł się w granicach jego państwa. Pośredniego dowodu na istnienie diecezji morawskiej w X wieku dostarczył Kosmas, opisując granice biskupstwa praskiego, które za rządów Ditmara obejmowało jedynie teren Kotliny Czeskiej, z wyłączeniem Moraw ${ }^{\text {III }}$. Odrębność pod względem kościelnym terenów w dorzeczu Morawy i Dyi, wyraźnie dokumentują tzw. listy Pilgrima ${ }^{\mathrm{II2}}$

Eight- to tenth-century Bohemia, s. 303-309 oraz s. 305, mapka 9, przedstawiająca rozmieszczenie madziarskich znalezisk na terenie Moraw i Kotliny Czeskiej.

106 Granum cathalogi prsesulum Moravia, MMFH I, s. 314-315. Od czasu śmierci biskupa Sylwestra aż do wyboru na biskupa praskiego Wojciecha, diecezja morawska podlegać miała Ratyzbonie, co nie znajduje potwierdzenia w materiale źródłowym, jak np. listy biskupa passawskiego Pilgrima, zob. przyp. 108.

107 Czołowym zwolennikiem tego poglądu był L.E. Havlík, Morava v 9.-Io. století, który bardzo mocno akcentował wartość historyczną Granum. To pozwoliło mu na wysunięcie hipotezy o ciągłości episkopalnej na Morawach nawet do połowy X w.

108 Należał do tej grupy F. Graus, Velkomoravská šiše v české středoveěké tradici, „Československý Časopis Historický” II(3) 1963, s. 295-297, akceptujęcy jedynie możliwość przetrwania niektórych elementów tradycji z okresu wielkomorawskiego. Natomiast ciągłość organizacji kościelnej w omawianym okresie stanowczo odrzucał D. Třeštík, Pád velké Moravy, s. 4I-62.

109 Codex diplomaticus et epistolaris regni Bohemiae I, ed. G. Friedrich, Pragae 1904, nr 34, s. 40-4I (dalej cyt. CDB); nowsza edycja Codex diplomaticus et epistolaris Slovaciae, I, ed. R. Marsina, Bratislava I97II, nr 47, s. 46.

110 V. Richter, Podivin, Zekirkostel a Slivnice, „Sborník Prací Filosofické Fakulty Brnenské University” F7, 1958: 2, s. 68-87, zwł. s. 72.

111 Kosmas, Chronica, I, c. 23, s. 45; II, c. 27, s. I2I.

112 Biskup ten w oparciu o sprokurowane dokumenty starał się wykazać zasługi jego diecezji w chrystianizacji okolicznych ludów a przede wszystkim udowodnić ciągłość funkcjonowania tradycji kościelnej w Passawie od czasu antyku. Celem tych działań było uzyskanie statusu arcybiskupstwa. O listach Pilgrima zob. MMFH 3, Epp. Nr I22, s. 255-259; I29, s. 267-27I, I3I, s. $272-273$; I32, s. 273. 
a także dokument z Io86 roku, który ujawnia aspiracje biskupa Jaromira-Gebharda do podporządkowania Pradze diecezji morawskiej ${ }^{\text {I3 }}$.

Welehrad, jako domniemane centrum kościelne państwa (wielko-)morawskiego w okresie działalności arcybiskupa Metodego, bez związku ze źródłami z IX wieku, pojawił się dopiero w historiografii czeskiej późnego średniowiecza ${ }^{\mathrm{II} 4}$ (kroniki, żywoty, legendy), szczególnie licznie za rządów cesarza Karola IV Luksemburskiego ${ }^{\mathrm{I5}}$. Dotycząca Moraw tradycja kościelna reprezentowana przez Granum cathalogi, jako miejsce, gdzie znajdowała się rezydencja biskupia, również wymienia Welehrad ${ }^{116}$, podczas gdy Augustyn Käsenbrant wskazuje Polešovice, jako miejsce, w którym rezydował biskup Jan ${ }^{117}$. Sporządzając wykaz biskupów morawskich wykorzystał on treść Granum, zamieszczając szersze komentarze przy imionach kolejnych biskupów sprawujących władzę kościelną na Morawach. Natomiast V. Richter opowiedział się za Podivinem jako miejscem, w którym znajdowała się siedziba biskupa, skąd dopiero później została przeniesiona do położonego na północy Ołomuńca ${ }^{\mathrm{II} 8}$. Ożywienie tradycji cyrylometodiańskiej w późnym średniowieczu w Czechach było rezultatem założenia przez cesarza Karola IV w 1347 roku klasztoru benedyktynów słowiańskich. Nie można wykluczyć, że za Luksemburgów na gruncie historiografii rozwinęły się idee i koncepcje, których celem było przedstawienie nowej dynastii jako „rodzimej”. Wzmocnieniu pozycji Luksemburga na tronie czeskim służyć miało powstanie z jego inspiracji nowego opracowania żywotów św. Wacława i Prokopa, w których znalazł się także wątek „morawski”, nawiązujący do Welehradu jako miejsca, gdzie znajdowała się siedziba arcybiskupa Metodego. W ożywieniu tradycji kościelnej z okresu działalności Metodego w Czechach w późnym średniowieczu ważną rolę odegrał klasztor benedyktynów słowiańskich w Pradze (Emauz), a także rozwój ruchu husyckiego, którego zwolennicy bardzo wyraźnie akcentowali związek z działalnością Konstantyna (Cyryla) i Metodego ${ }^{\text {II }}$. W tekstach późnośredniowiecznych związanych z diecezją oło-

113 CDB, I, 86, s. 92-95. Dokument ten posiada bogatą literaturę przedmiotu, zob. M. MatlaKozłowska, Pierwsi Przemyslidzi, s. 170-219.

114 Život svatých Crha a Strachoty, MMFH 2, s. 314-316.

115 Nowe opracowanie żywotów św. Wacława, Diffundente sole, MMFH 2, s. 285-288 oraz legendy rozpoczynającej się od słów: Quemadmodum ex historii beatus Crillus et Metodius, MMFH 2, s. 29I-296 a także Vita Santi Wenceslai auctore Carolo IV, MMFH 2, c. I, s. 298.

116 MMFH I, s. 314, 316. Z tekstu Granum wynika, że po śmierci Metodego siedzibą biskupów morawskich był Welegrad quomodam sedem metropolita nam in ecclesia Santi Petri, (s. 316), tym samym nawiązując do okresu wielkomorawskiego (s. 314). Zatem dzieje biskupstwa ołomunieckiego stanowiły kontynuację z okresu działalności arcybiskupa Metodego. Tekst Granum jest dowodem na występowanie w omawianym okresie żywej tradycji wielkomorawskiej, związanej nie tylko z klasztorem cystersów w Welehradzie, lecz także w środowisku ołomunieckim. V.Vavř́nek, The question of the legendary Welegrad (Velehrad) as the al legend seat of the Morawian archibishop Methodius, „Slovo”2010, 60, s. 771-790.

117 Augustini olonucensis episcoporum olomucensium series, MMFH 4, s. 435 (oppidio Polessowicz, a także alternatywna miejscowość - Kunovice). Źródło to wykazuje ścisłą zależność od tekstu Granum.

118 V. Richter, Podivin, Zekirkostel a Slivnice, s. 72.

119 M. Kopecký, Cirilometodějská tradice v starši české literatuře, [w:] Magna Moravia, s. 567-586, zwł. s. $572-573$. 
muniecką występują reminiscencje wielkomorawskiej tradycji kościelnej, jakkolwiek arcybiskup Metody nie został wymieniony w katalogu wraz z innymi miejscowymi biskupami. Może to przemawiać za utrzymaniem się w tamtejszym środowisku kultu Braci Sołuńskich oraz tradycji związanej z Weligradem, jako domniemaną siedzibą arcybiskupa Metodego. Jednak hipoteza o przetrwaniu organizacji kościelnej na terenie Moraw co najmniej do połowy X wieku, za czym opowiadał się L.E. Havlík, nasuwa wątpliwości. Nawet zakładając, że jeden z sufraganów reaktywowanej metropolii przetrwał upadek państwa Mojmira II, to niewiadomą pozostaje podległość hierarchiczna tego biskupa (-ów), trudno też ustalić, kto i kiedy dokonałby konsekracji jego następcy. Brak także możliwości aktywnego wsparcia ze strony władzy politycznej, a to nie pozostawało bez wpływu na możliwości funkcjonowania tej diecezji. Długi okres czasu, jaki upłynął od nominacji papieskiej Jana IX z 899 roku aż do momentu konsekracji nieznanego z imienia biskupa morawskiego na synodzie w Moguncji w 976 stawia pod znakiem zapytania kwestię kontynuacji którejś z sufraganii. Obecny stan badań skłania więc do zaakceptowania stanowiska, że upadek Wielkich Moraw przed 907 rokiem miał negatywny wpływ na działającą na tym obszarze organizację Kościoła, której funkcjonowanie w tych warunkach było bardzo trudne, jeżeli nie niemożliwe.

\section{Liturgia i piśmiennictwo stowiańskie $w$ Czechach $w X$ wieku}

W dyskusji dotyczącej rozwoju kultury chrześcijańskiej w Czechach w omawianym okresie poczesne miejsce zajmuje kwestia występowania liturgii i piśmiennictwa staro-cerkiewno-słowiańskiego. Studia slawistyczne wykazały obecność licznych śladów pochodzących z języka czeskiego (bohemizmy) w ruskich i chorwackich redakcjach tekstów liturgicznych ${ }^{\mathrm{I20}}$. Na tej podstawie wysunięto pogląd o występowaniu w państwie czeskim w X-XI wieku silnego nurtu piśmiennictwa w języku staro-cerkiewno-słowiańskim, będącego pokłosiem dziedzictwa cyrylometodiańskiego. Niezależnie od zajmowanego stanowiska w tej kwestii, aktualnymi i wzbudzającymi liczne kontrowersje pozostają pytania, czy piśmiennictwo to występowało nieprzerwanie od czasu chrztu Borzywoja I i przynależności Kotliny Czeskiej do państwa (wielko-)morawskiego, czy może był to rezultat działalności środowiska benedyktynów klasztoru w Sázavie? Czy w X wieku obok liturgii łacińskiej w Czechach współwystępowały liturgia i piśmiennictwo słowiańskie?

W pochodzącym z XVI wieku rękopisie zawierającym tekst żywota św. Wacława, który został odnaleziony przez rosyjskiego slawistę A.Ch. Wostokowa i opublikowany w I827 roku, znajduje się wzmianka o nauce i znajomości języka staro-cerkiewno-słowiańskiego przez młodego księcia. Informację tę zawierają wersje legendy powstałe $\mathrm{w}$ środowisku ruskim i chorwackim, natomiast nie występują one w tekstach łacińskich żywota św. Wacława, przede wszystkim w tzw. legendzie Krystiana. Na ogół uważa się,

120 Zestawił je i omówił F.V. Mareš, Die slawische liturgie in Böhmen zur Zeit des Grüdung des Prager Bistums, [w:] Millenium dioecesis Pragensis 973-1973, „Annales Instituci Slavici” 1974, 8, s. 95-IIO. 
że tekst powstał wkrótce po śmierci Wacława. Dotychczas najczęściej wskazywano na środowisko klasztoru Benedyktynów w Sázavie jako głównego „łącznika” w utrzymaniu ciągłości piśmiennictwa staro-cerkiewno-słowiańskiego na terenie Czech od końca IX do XI wieku. Jednak duża liczba tekstów w redakcji chorwackiej i ruskiej zawierających czeskie wpływy leksykalne przemawia za tym, aby interesujący nas nurt piśmiennictwa w Czechach datować jeszcze przed powstaniem wymienionego klasztoru. Nasuwa się pytanie - od kiedy możemy mówić o jego początkach? Z dotychczasowych rozważań należy wykluczyć okres rządów Borzywoja I, albowiem nie dysponujemy danymi źródłowymi, które potwierdzałyby występowanie w Czechach liczniejszego środowiska duchownych przybyłych z terenu Moraw i kultywujących posługiwanie się pismem głagolickim. Stąd J. Leśny zwrócił uwagę na pośrednictwo bawarskie w rozwoju piśmiennictwa słowiańskiego w Czechach w początku X wieku. Dotyczyło to przede wszystkim biskupstwa ratyzbońskiego, w którego jurysdykcji znalazły się plemiona czeskie od połowy lat dziewięćdziesiątych IX wieku. Możliwe zatem, że zaistniało wykorzystanie w praktyce nurtu piśmiennictwa starostowiańskiego (...) u boku dziatających w tym kraju misjonarzy z ośrodków niemieckich, rzecz jasna - nieoficjalnie, konstatował poznański slawista ${ }^{\text {I2I }}$. Stanowisko, jakie zajął w tej kwestii wymieniony badacz, jest zasadne, jeżeli weźmiemy pod uwagę praktyki duszpasterskie Kościoła zachodniego, które - wbrew obiegowej opinii, nie było przeciwnikiem wykorzystania w praktyce do celów misyjnych miejscowego narzecza bądź języka. Diecezje bawarskie znane były z podejmowanych prób opracowania alfabetu słowiańskiego dla celów duszpasterskich (Zabytki fryzyńskie). Dlatego też rozwój kultury chrześcijańskiej opartej na bilingwizmie w Czechach w X wieku nie byłby nie do pomyślenia.

Przy tej okazji powraca kwestia działalności duchownych z kręgu arcybiskupa Metodego, którzy po jego śmierci znaleźli schronienie na terenie Kotliny Czeskiej. Czy jednak skala tej emigracji była na tyle liczna? Wiadomo, że grupa najbliższych współpracowników Metodego znalazła się na terenie państwa bułgarskiego, a znaczna liczba duchownych trafiła do Wenecji (gdzie znajdowało się jedno z głównych targowisk handlu niewolnikami w Europie) jako niewolnicy, skąd zostali wykupieni przez posła bizantyjskiego i skierowani do pracy kapłańskiej na terenie Dalmacji. Skala represji, jaka dotknęła duchownych podlegających arcybiskupowi Metodemu, stawia pod znakiem zapytania możliwość licznej emigracji tej grupy do sąsiedniej Kotliny Czeskiej, która zresztą niebawem również znalazła się pod bezpośrednią władzą księcia morawskiego Świętopełka. Wobec licznych wątpliwości związanych z rozwojem piśmiennictwa głagolickiego w Czechach, zwłaszcza w pierwszej połowie X wieku, wynikających z braku odpowiedniej podstawy źródłowej, spotkać można opinie, że występowanie odpowiednich warunków do jego rozwoju miało miejsce albo dopiero pod koniec stulecia, albo dopiero XI wieku, kiedy powstał klasztor w Sázavie ${ }^{\mathrm{I2} 2}$

121 J. Leśny, Konstantyn i Metody, s. IO4.

122 D. Třeštík, Počatký Přemyslovcư, s. 366 sceptycznie odnosił się do możliwości istnienia piśmiennictwa głagolickiego w Czechach na początku X wieku. Z kolei zdaniem O. Kralíka, Sázavské pismenictví, s. 58 najbardziej odpowiednie warunki do rozwoju tego nurtu piśmiennictwa 
(będący pomostem pomiędzy dziedzictwem wielkomorawskim a tradycją kościelną i kulturową Czech w omawianym okresie), bądź nawet jeszcze później ${ }^{123}$. Najbardziej kontrowersyjna kwestia w dotychczasowej dyskusji dotyczy okresu IX wiek - pierwsza połowa X stulecia, kiedy teren Kotliny Czeskiej podlegał politycznym i kościelnym wpływom Bawarii.

Odkrycie pierwszej starosłowiańskiej legendy św. Wacława w redakcji ruskiej oraz kolejnych, tym razem w wersji chorwackiej, spowodowało pojawienie się poglądu o rozwoju piśmiennictwa i liturgii z językiem staro-cerkiewno-słowiańskim (głagolica) w Czechach za pierwszych Przemyślidów. O ile jednak redakcja ruska jest późna, pochodzi bowiem dopiero z XVI-XVII wieku, o tyle najstarsza znana wersja chorwacka legendy św. Wacława pochodzi z XIV stulecia i uważana jest za najbliższą pierwowzorowi. Dyskusja wokół udziału i skali rozwoju piśmiennictwa głagolickiego w Czechach w X wieku zogniskowała się wokół dwóch zagadnień, z których pierwsze odnosi się do ustalenia czasu powstania najstarszego żywota św. Wacława, natomiast drugie - określenia powiązań pomiędzy wersją czeską a chorwacką. Za powstaniem legendy w X wieku opowiedział się O. Králík, łącząc jej genezę z okresem działalności biskupa Wojciecha, którego uważał za propagatora kultury słowiańskiej ${ }^{\mathrm{r} 24}$. Do powyższych ustaleń nawiązał też $\mathrm{D}$. Třeštík, formułując pogląd o powstaniu tekstu pierwszej staro-cerkiewno-słowiańskiej legendy o św. Wacławie pod koniec X wieku. Nazwał ją legendą X, która stała się pierwowzorem dla wszystkich żywotów św. Wacława, i z której korzystali autorzy jego biografii ${ }^{125}$. Ponadto historyk ten powstanie legendy X, napisanej w języku łacińskim (za czym przemawia wykorzystanie tego tekstu przez autorów żywota św. Wacława - biskupa Mantui, Gumpolda, czy Wawrzyńca, mnicha z klasztoru na Monte Cassino, którzy przecież nie znali języka słowiańskiego) datował przed erygowaniem biskupstwa w Pradze ${ }^{126}$. Jego zdaniem ${ }^{127}$, pierwszą starocerkiewno-słowiańską legendę trzeba łączyć z rozwojem kultu św. Wacława, którego

przypadły dopiero na okres, kiedy w Pradze trwały rządy biskupa Wojciecha Sławnikowica. Natomiast P. Вечерка (R. Večerka), Великоморавские истоки церковнославянской письменности и Чешском княжестве, [w:] Magna Moravia, s. 493-524 na podstawie argumentów filologicznych opowiedział się za występowaniem i rozwojem piśmiennictwa staro-cerkiewno-słowiańskiego w Czechach, poczynając od działalności misji bizantyjskiej w państwie Rościsława i Świętopełka I, aż po fundację klasztoru w Sázavie.

123 Do sceptyków wczesnego datowania rozwoju piśmiennictwa głagolickiego w Czechach należał F. Graus, Velkomoravská ríše v česke středověké tradici, Čs Čh 1963: II(3), s. 289-305, który przyjmował, że doszło do tego dopiero w okresie późnego średniowiecza.

124 O. Králík, Kpočátkom literatury v premyslovských Čechách (Rozpravy ČSAV. ŘSV, 7O(6), Praha I960; Tenże, Nová fáze sporu o slovanskou kulturu v premyslovských Čechách, „Slavia” 1968:37, s. 474-494.

125 D. Třeštík, Počatký Přemyslovcư, s. 223-248. Badacz, w przeciwieństwie do O. Králíka, uważał, że legenda ta powstała niezależnie od bawarskiej wersji żywota św. Wacława (Crescende fide).

126 Tamże, s. 248, zamieszczony został schemat przedstawiający powiązania pomiędzy legendą X a późniejszymi tekstami żywotów św. Wacława i Ludmiły.

127 Tenże, Staroslovenská liturgie a pismennictvi v Čechich Io. století, [w:] Svatý Prokop, Čechy a stčední Europa, red. P. Sommer, Praha 2006, s. 189-218, zwł. s. 192. 
początek należy upatrywać w translacji szczątków męczennika do Pragi. Inicjatorem zaś tego przedsięwzięcia był książę Bolesław I.

Za związkami czeskiego piśmiennictwa staro-cerkiewno-słowiańskiego z terenem Chorwacji opowiedział się D. Třeštík, wskazując akta synodu splickiego (925), z których miał pochodzić występujący w legendzie św. Wacława motyw Judasza ${ }^{\mathrm{I2}}$. Jednak koncepcja ta spotkała się z krytyką, ze względu na to, że postać ta znana była powszechnie z Nowego Testamentu i nie było potrzeby, aby autor pierwszej legendy słowiańskiej zmuszony był sięgać do splickich akt synodalnych, by za ich pośrednictwem wprowadzić ją do tekstu legendy. Ponadto w toku dyskusji zwrócono także uwagę na brak w Chorwacji instytucji notariusza w omawianym okresie ${ }^{129}$.

Porównanie przez autora pierwszej starosłowiańskiej legendy postępowania możnych, którzy nie dotrzymali wierności księciu, do postawy Judasza wobec Jezusa, było nowym elementem. We fragmencie tym widać bardzo czytelne nawiązanie do elementu ówczesnej kultury politycznej, jakim było podkreślenie dominującej roli księcia jako alter ego władzy Chrystusa na ziemi. Pojawienie się tego wątku w pierwszej starosłowiańskiej legendzie św. Wacława ukazuje realia historyczne Czech w X wieku i pozwala zrozumieć powody, dla których autor żywota popularny motyw wykorzystał do oceny czeskich możnowładców.

Hipoteza o utrzymaniu się w Czechach w X wieku piśmiennictwa cyrylometodiańskiego oparta została także o informację pochodzącą z pierwszej staro-cerkiewno-słowiańskiej legendy o św. Wacławie o edukacji przyszłego księcia i świętego: znajomości ksiąg łacińskich i słowiańskich. Posłużyła ona też do przyjęcia tezy o istnieniu w grodzie Budeč szkoły bądź skupiska duchownych ze znajomością języka i pisma głagolickiego. D. Třeštík uznał powyższą wzmiankę za późniejszy dodatek, mający na celu przedstawienie piśmiennictwa staro-cerkiewno-słowiańskiego w korzystnym świetle ${ }^{\mathrm{r} 30}$. Pogląd ten znajduje potwierdzenie w dotychczasowych badaniach historyczno-literackich, które nie wykazują danych świadczących o rozwoju tego nurtu piśmiennictwa w Czechach w pierwszej połowie X wieku.

$\mathrm{Z}$ drugiej strony, wzmianka o edukacji młodego Wacława może stanowić dowód bilingwicznego charakteru ówczesnej kultury w państwie Przemyślidów. Zazwyczaj stanowi to podstawę do stawiania tezy o utrzymaniu się ciągłości kulturowej i religijnej dziedzictwa cyrylometodiańskiego w Czechach, od chrztu księcia Borzywoja I aż po

128 D. Třeštík, Miscellanea k. I. staroslovenskè legendę o sv. Václavu. „Každý kto povstává proti panu svèmu, podoben jest Jidaši””, „Československý časopis historický” 1967:15, s. 337-343.

129 V. Konzal, Staroslovenskè legendy českèho pưvodu, Praha 1976, s. 80.

130 D. Třeštík, Počatký Přemyslovců, s. 366-369, dostrzegał jeszcze inny aspekt związany z edukacją młodego Wacława w grodzie, w którym przebywała Ludmiła. Dotyczył on rywalizacji pomiędzy Ludmiłą a jej synową, Drahomirą. Dlatego też pobyt młodego Wacława w Budeczu stanowił dowód wysokiej pozycji, jaką Ludmiła zajmowała w państwie. Jeszcze innym, nie mniej istotnym powodem narastającego wewnątrz rodu Przemyślidów konfliktu, były napięcia w stosunkach pomiędzy Saksonią a Bawarią, co na początku lat dwudziestych X wieku nie pozostało bez wpływu na księstwo czeskie, jako najbliższego sąsiada. W tym kontekście rozpatrywać należy zamordowanie Ludmiły (I5 IX 92I) przez wynajętych drużynników Drahomiry. 
utworzenie biskupstwa w Pradze. Ważnym argumentem w tej dyskusji jest kronika Kosmasa, w której znajduje się fragment pochodzący z bulli papieskiej adresowanej do biskupa praskiego, a odnoszący się do zakazu praktykowania w niej rytu bułgarskiego bądź ruskiego ${ }^{\mathrm{I3}}$. Wybitny czeski slawista F.V. Mareš uważał tę informację za autentyczną, jednak bardziej przekonuje argumentacja A. Avenariusa, który zwracał uwagę, że wymienienie przez kronikarza rytu ruskiego pozostaje bardziej zrozumiałe i lepiej osadzone w realiach kościelno-kulturowych Czech XI wieku w powiązaniu z działalnością klasztoru w Sázavie (IO32), aniżeli reminiscencje bułgarskie ${ }^{\mathrm{I} 2}$.

\section{Podsumowanie}

Chrześcijaństwo na teren Czech dotarło poprzez sąsiednie Morawy oraz Bawarię, która już od końca IX wieku zaczęła odgrywać coraz znaczniejszą rolę. Jednak prowadzenie systematycznej i zorganizowanej pracy misyjnej możemy zaobserwować dopiero od czasu założenia biskupstwa w Pradze. Znacznie wolniej natomiast przebiegała zmiana mentalności i kształtowanie się kultury religijnej ludności pod wpływem oddziaływania nowej religii. W Czechach proces ten widoczny był aż do lat czterdziestych XI wieku i - analogicznie jak w pozostałych krajach regionu - także zależny był od postępów w zakresie budowy organizacji państwowej. Pozycja księstwa czeskiego w realiach politycznych i kulturowych Europy wczesnego średniowiecza oraz posiadanie aż dwóch kanonizowanych członków dynastii zapewniło Przemyślidom wysoką pozycję wśród rodów panujących, które kształtowały dzieje i kulturę Europy Środkowej.

Do Czech chrześcijaństwo dotarło poprzez sąsiednie Morawy oraz Bawarię, która już od końca IX w. zaczęła odgrywać coraz znaczniejszą rolę. Jak ukazują rezultaty badań historycznych i archeologicznych aż do połowy X w. jego zasięg ograniczał się do domeny Przemyślidów (Kotlina Praska). Szerzenie się nowej religii było rezultatem działań podjętych przez Wacława I i Bolesława I. Jednak prowadzenie systematycznej i zorganizowanej pracy misyjnej było utrudnione przez brak wystarczającej liczby duchownych, szkół oraz własnego biskupstwa (973). Znacznie wolniej natomiast przebiegała zmiana mentalności i kształtowanie się kultury religijnej ludności pod wpływem oddziaływania nowej religii. W Czechach proces ten widoczny był aż do lat czterdziestych XI w. i analogicznie jak w pozostałych krajach regionu, także zależny był od postępów w zakresie budowy organizacji państwowej. W badaniach historycznych i filologicznych zwraca się uwagę na bilingwialny charakter kultury w państwie

131 Kosmas, Chronica, I, c. 22, s. 44.

132 A. Avenarius, Byzantská kultura, s. I04-Io6. Ich pojawienie się to rezultat rozwoju kontaktów handlowych kupców czeskich w strefie dolnego Dunaju w X w., co znalazło odzwierciedlenie w dziele mnicha Krystiana. W kwestii relacji z Rusią zob. R. Nový, Slavnikovici, s. 48. 
Przemyślidów, jakkolwiek brak przekonujących dowodów potwierdzających występowanie ciągłości kulturowej i religijnej dziedzictwa cyrylometodiańskiego w Czechach. Pozycja księstwa czeskiego w realiach politycznych i kulturowych Europy wczesnego średniowiecza oraz posiadanie aż dwóch kanonizowanych członków dynastii zapewniło Przemyślidom wysoką pozycję wśród rodów panujących, które kształtowały dzieje i kulturę Europy Środkowej.

SŁOWA KLUCZOWE

Czesi, państwo czeskie, Czechy i Morawa, chrystianizacja, Przemyślidzi, Cyryl (Konstantyn i Metody, św. Wacław, X wieku, Europa Środkowa

ABSTRACT

Beginnings and development of Christianity in the Czech for the first Przemyslids (by the end of the tenth century)

Christianity came to the Bohemia through neighboring Moravia and Bavaria, which from the end of the $9^{\text {th }}$ century began to play an increasingly important role. As shown by the results of historical and archaeological research, up to the middle of the $\mathrm{IO}^{\text {th }}$ century its range was limited to the domain of Přemyslid' (Praga's Basin). The spreading of a new religion was the result of actions taken by Wenceslas I and Boleslav I. However, the conduct of systematic and organized missionary work was hampered by the lack of sufficient clergy, schools and own bishopric (973). Much more slowly, however, was the change in the mentality and shaping of the religious culture of the population under the influence of the new religion. In the Czech State, this process was visible until the forties of the $\mathrm{II}^{\text {th }}$ century and - similarly to other countries of the region - it was also dependent on the progress in the construction of a state organization. In historical and philological studies, attention is paid to the cultural characteristic of the Přemyslid' family, although there is no convincing evidence of the continuity of the cultural and religious heritage of Slavonic liturgy and script in the Bohemia. The position of the Czech principality in the political and cultural realities of Europe of the early Middle Ages and the possession of two canonized members of the dynasty (Saint Ludmila and Saint Wenceslas) provided the Přemyslid' family with a high position among the ruling houses that shaped the history and culture of Central Europe.

KEYWORDS

Czechs, Bohemian State, Bohemia and Moravia, Christization, Přemyslids, SS. Cyril and Methodius, S. Wenceslas, Io $^{\text {th }}$ century, Central Europa 